Wilfrid Laurier University

Scholars Commons @ Laurier

Biology Faculty Publications

Biology

4-2005

\title{
The Biology of Canadian Weeds. 131. Polygonum aviculare L.
}

Mihai Costea

Wilfrid Laurier University, mcostea@wlu.ca

François J. Tardif

University of Guelph

Follow this and additional works at: https://scholars.wlu.ca/biol_faculty

Part of the Biology Commons

\section{Recommended Citation}

Costea, Mihai and Tardif, François J., "The Biology of Canadian Weeds. 131. Polygonum aviculare L." (2005). Biology Faculty Publications. 76.

https://scholars.wlu.ca/biol_faculty/76

This Article is brought to you for free and open access by the Biology at Scholars Commons @ Laurier. It has been accepted for inclusion in Biology Faculty Publications by an authorized administrator of Scholars Commons @ Laurier. For more information, please contact scholarscommons@wlu.ca. 


\title{
The biology of Canadian weeds. 131. Polygonum aviculare L.
}

\author{
Mihai Costea ${ }^{1}$ and François J. Tardif ${ }^{2}$ \\ Department of Plant Agriculture, Crop Science Building, University of Guelph, Guelph, Ontario, \\ Canada N1G 2W1 (e-mail: ${ }^{1}$ coste_amihai@hotmail.com and ${ }^{2}$ ftardif@uoguelph.ca). \\ Received 14 October 2003, accepted 4 October 2004.
}

\begin{abstract}
Costea, M. and Tardif, F. J. 2005. The biology of Canadian weeds. 131. Polygonum aviculare L. Can. J. Plant Sci. 85: $481-506$. A review and assessment of biological information as well as personal data are provided for Polygonum aviculare in Canada. The species has been revised taxonomically and the six subspecies that occur in Canada are presented. Three of the subspecies, $P$. aviculare subsp. aviculare, $P$. aviculare subsp. neglectum and $P$. aviculare subsp. depressum are weeds introduced to Canada from Europe. A fourth subspecies, P. aviculare subsp. buxiforme is apparently native to North America. The geographical distribution of the latter four subspecies is very wide. Plants exhibit a high phenotypic plasticity and genetic variability, and they easily adapt to a multitude of agrestal and ruderal habitats. The seeds have a variable dormancy and polymorphic germination as a result of heterocarpy, genetic and environmental factors. In other areas (Europe), the species has developed resistance to triazines. Plants are hosts to nematodes, viruses, and fungi that also affect cultivated plants.
\end{abstract}

Key words: POLAV, ecology, distribution, taxonomy

Costea, M. et Tardif, F. J. 2005. La biologie des mauvaises herbes au Canada. 131. Polygonum aviculare L. Can. J. Plant Sci. 85: 481-506. Le présent article brosse un tableau et évalue les données biologiques et quelques données personnelles sur Polygonum aviculare au Canada. La taxonomie de cette espèce a été révisée et les auteurs présentent les six sous-espèces acclimatées au Canada. Trois d'entre elles, à savoir $P$. aviculare ssp aviculare, $P$. aviculare ssp neglectum et $P$. aviculare ssp depressum ont été introduites d'Europe. Une quatrième, $P$. aviculare ssp buxiforme, est apparemment indigène à l'Amérique du Nord. Cette dernière se caractérise par une très vaste répartition géographique. Les plants montrent une grande plasticité du phénotype et une forte variabilité génétique, qui leur permettent de s'adapter aisément à une multitude de milieux agrestes et rudéraux. La dormance des graines varie et l'hétérocarpie, les paramètres génétiques ainsi que les facteurs environnementaux expliquent leur germination polymorphe. Ailleurs (Europe), l'espèce a acquis une résistance aux triazines. La plante sert d'hôte à des nématodes, à des virus et à des champignons qui s'attaquent aux espèces cultivées.

Mots clés: POLAV, ecologie, répartition, taxonomie

\section{Names}

Polygonum aviculare L. (POLAV)

I. subsp. aviculare (= $P$. aviculare sensu stricto)-prostrate knotweed, renouée des oiseaux (Darbyshire et al. 2000), POLAA.

II. subsp. depressum (Meisn.) Arcang. (= P. arenastrum Boreau) - oval-leaved knotweed, renouée à petits fruits (Darbyshire et al. 2000), POLAR.

III. subsp. neglectum (Besser) Arcang. (= P. neglectum Besser), POLNG.

IV. subsp. buxiforme (Small) Costea \& Tardif $(=P$. buxiforme Small)

For a list of synonyms and notes on the nomenclature see Karlsson (2000), Costea and Tardif (2003a), Costea et al. (2004).

Polygonaceae (Smartweed family), Polygonacées, subfamily Polygoneae. The genus name comes from the Greek words "poly"-many and "gonum"- joint or knee, referring to the obviously articulated stems. Early botanists probably observed the dispersal of the seeds by birds, because the specific epithet "aviculare" means in Latin "of birds".

\section{Description and Account of Variation}

Some of the less known botanical terms are marked with an asterisk in the text and explained in Appendix 1 (Hoen 1999; Kiger and Porter 2001).

(a) Description - Seedlings - with a short hypocotyl (0.5-3 $\mathrm{cm}$ ), linear* cotyledons $10-15 \times 1-1.5 \mathrm{~mm}$, with a rounded apex. The first leaves are more or less lanceolate*, with a white-membranous ocrea at the base (see below). Mature plants-Plants are annual, with a taproot. Kutschera (1960) described the roots of adult plants of $P$. aviculare, grown in an alluvial type of soil. The root system consisted of a dense region of horizontal secondary roots distributed in the upper 15-25 cm layer of soil, and the main root, which, together with a few secondary vertical branches, reached depths of up to $70 \mathrm{~cm}$ (Kutschera 1960, Fig. 74). The primary roots are $0.3-0.6 \mathrm{~mm}$ in diameter and the secondary roots are less than $1 \mathrm{~mm}$ in diameter (Kutschera and Sobotik 1992). Stems are obviously and regularly $8-16$ ribbed, prostrate to erect, 6 to $200 \mathrm{~cm}$ long. Plants may be homophyllous, when stem and branch leaves are more or less of the same size, or heterophyllous, when main stem leaves are markedly (at least 
three times) larger than the leaves on the lateral branches. The ocrea (plural: ocreae) is a tubular sheath surrounding the stem nodes and petiole bases, which characterizes all Polygonaceae; it is 3-16 mm, with a few to many, weak to strong veins; the free part is silvery, more or less persistent, soon disintegrating into persistent brown fibers, or, leaving no fibrous remains. Leaves are alternate; petioles are short; blades are green to gray- or bluish-green, very narrowly elliptic*, lanceolate*, elliptic* or obovate*; margins are entire; apex is acute, obtuse or rounded. Primary inflorescences are axillary cymes with 2 to 6 (sometimes up to 8) flowers. Cymes may be equally distributed along the stem and branches or aggregated towards the top of the stem and branches. Flowers are bisexual, short pedicillate; perianth is petaloid; tepals* 5 , fused, forming a tube that is $20-55 \%$ of the perianth length, the outer 3 tepals are oblong to obovate, often becoming cucullate* in fruit, green with white, pink or red borders; tepal midveins are branched or unbranched, thickened or not; stamens are 5-8. Achenes are light brown to dark brown, trigonous (three-angled), ovate, $1.7-4 \mathrm{~mm}$ long, enclosed in the perianth or exserted at maturity, faces subequal or unequal, usually coarsely striate-tubercled, sometimes obscurely tubercled, with tubercles limited to a few rows on central parts of faces; heterocarpy is common (see section $8 b$ )

Chromosome numbers-Polygonum aviculare is a polyploid complex with a basic chromosome number of $x=10$. Wolf and McNeill (1987) did 183 chromosome counts on plants from eastern Canada and the United States and reported only tetraploids and hexaploids. Polygonum aviculare subsp. aviculare, subsp. neglectum and subsp. depressum have $2 n=6 x=60$ or $2 n=4 x=40$. Plants of $P$. aviculare subsp. aviculare are more frequently hexaploids, while plants of subsp. depressum and subsp. neglectum are usually tetraploids. Polygonum subsp. buxiforme has $2 n=$ $6 x=60$ (Wolf and McNeill 1987). Chromosome counts of $P$. aviculare subsp. rurivagum (Jordan ex Boreau) Berher are available only from Europe-2n=6x=60 (Styles 1962). Yurtseva and Kramina (2003) reported chromosome counts of $2 n=2 x=20$ for $P$. aviculare subsp. depressum from Russia. Other world-wide chromosome counts have been reviewed by Wolf and McNeill (1987) and by Missouri Botanical Garden (2004).

b. Distinguishing features-Polygonum aviculare is very similar to other Polygonum species from North America, but fortunately many of these species are not weeds. Bushy knotweed ( $P$. ramosissimum Michx.) and striate knotweed $(P$. achoreum $\mathrm{S}$. F. Blake) are the only species that may occur as weeds and may be confused with $P$. aviculare. However, plants of $P$. ramosissimum have a yellowish tinge, tepals are green-yellow with yellow borders, and achenes are usually smooth. Polygonum achoreum is distinguished by its elliptic leaves, the yellowish, bottle-shaped perianth and the yellow-green to tan, uniformly tubercled achenes. Complete descriptions of these species and an identification key for all North American species can be found in Costea et al. (2005). Some spurge species, such as Euphorbia mac- ulata L., may be superficially similar to P. aviculare. Unlike prostrate knotweed, the spurges release a milky sap when cut and do not have ocreae. Young seedlings of $P$. aviculare are sometimes mistaken for grass species, but the leaves of the latter are parallel-veined and do not possess ocreae.

(c) Intraspecific variation-Polygonum aviculare is a taxonomically controversial polyploid complex of selfing annuals. There are two opposite taxonomic concepts regarding the delimitation of $P$. aviculare as a species:

1. Polygonum aviculare, the narrow sense (P. aviculare sensu stricto $=P$. aviculare subsp. aviculare in this study; e.g., Mertens and Raven 1965; Wolf and McNeill 1987). The recognition of a narrow sense of $P$. aviculare is based on the study of Styles (1962), who reported sharp discontinuities between some of the species of the $P$. aviculare complex ( $P$. aviculare, $P$. arenastrum, $P$. boreale Lange and $P$. rurivagum Jordan ex Boreau), and the presumably different chromosome numbers of these taxa.

2. Polygonum aviculare, the broad sense ( $P$. aviculare sensu lato), which includes $P$. aviculare s.str., plus a variable number of closely related species that distinguished at the infraspecific level (e.g.,Chrtek 1956; Karlsson 2000; Costea and Tardif 2003a). This species concept is justified by the fact that the members of the $P$. aviculare complex are not characterized by any particular chromosome numbers (e.g., Gasquez et al. 1978; Wolf and McNeill 1987; Meerts et al. 1998). Furthermore, multivariate analysis and isoenzyme studies using many populations proved that these taxa are not well-differentiated, and populations with intermediate characteristics may occur (Meerts et al. 1990; Costea and Tardif 2003a). A broadly defined $P$. aviculare is suitable for practical reasons as well. Weed scientists and agronomists have pragmatically identified all the species of the $P$. aviculare complex under a single name-P. aviculare (sometimes erroneously as $P$. arenastrum-e.g., Royer and Dickinson 1999; Bubar et al. 2000) without further distinguishing its members. A broad sense of $P$. aviculare, which includes $P$. aviculare s.str., $P$. arenastrum, $P$. neglectum, $P$. buxiforme, $P$. rurivagum and $P$. boreale as subspecies, has been proposed for the Flora of North America (Costea and Tardif 2003a; Costea et al. 2005), and this is the taxonomic solution followed here. It is essential to emphasize that most of the ecology and biology studies reviewed in this account do not specify which member of the $P$. aviculare complex was under investigation.

\section{Identification Key to Subspecies of Polygonum aviculare}

1. Perianth tube is $40-57 \%$ of the perianth length.

2. Tepals* with borders white (sometimes reddishbrown in the innermost part) and/or unbranched veins IV. subsp. depressum

2. Tepals with pink to red margins and branched veins. .III. subsp. neglectum

1. Perianth tube is less than $40 \%$ of the perianth length.

3. Perianth 3.3-5.5 mm; achenes 2.7-4.2 mm long.

4. Heterophyllous; blades elliptic* to oblanceolate*; perianth to $4.7 \mathrm{~mm}$, outer tepals oblong, cucullate*; 
cymes aggregated at stem and branch apices .I. subsp. aviculare

4. Homophyllous or subheterophyllous; leaf spathulate*, obovate* to oblanceolate*; perianth to $5.5 \mathrm{~mm}$, outer tepals obovate, flat or outcurved; cymes \pm uniformly distributed.... VI. subsp. boreale 3. Perianth 1.9-3.4 mm; achenes 1.2-2.8(3) mm long. 5 .Ocreae with free part relatively persistent, silvery; perianth almost as wide as long or less than 1.5 times longer than wide, outer tepals with a pouch-like protrusion at the base ...............................................II. subsp. buxiforme 5. Ocreae soon disintegrating into persistent fibers or leaving almost no fibrous remains; perianth at least 1.5 times longer than wide; outer tepals without a pouch-like protrusion at base.

6. Blades 5-20 mm wide, 2-5 times longer than wide; cymes with 3-8 flowers congested at the apices of stems and branches; achenes included or with a barely visible tip (achene edges are not visible)................ subsp. aviculare 6. Blades 1-6 mm wide, 4.5-15 times longer than wide; cymes with 1-3 flowers, uniformly distributed on stems and branches and/or achene exserted, with achene edges visible.

7. Ocreae 4-8 mm long, with inconspicuous veins and free part leaving almost no fibrous remains; secondary leaf veins visible but not raised on lower part of blades .III. subsp. neglectum

7. Ocreae 7-12 $\mathrm{mm}$, with strong, brown veins and free part disintegrating into persistent fibers; secondary leaf veins strongly raised on lower part of blades . V. subsp. rurivagum

Polygonum aviculare subsp. boreale is rare on the seashores of Labrador and Greenland, and subsp. rurivagum is a rare ruderal in North America (Costea and Tardif 2003a, b). They are included in the identification key and described only for comparison (see also Costea and Tardif 2003a, b; Costea et al. 2005). Each subspecies has long list of synonyms, most of which are not given here but may be found in Costea et al. (2005).

I. Polygonum aviculare subsp. aviculare-Plants are green, distinctly heterophyllous, but often lacking the larger bottom stem leaves at maturity. The stems are 1-3, ascending, erect, or decumbent*; basal branches are divaricate*, $10-100 \mathrm{~cm}$ long. Ocreae are 6-12 $\mathrm{mm}$ long, with the free part silvery, soon lacerate* and disintegrating into fibers. Leaf blades are green, elliptic to oblanceolate* $18-55 \times$ 8-20 mm, 2-4.5 times as long as wide; apices acute or obtuse. Cymes have 3-8 flowers and they are aggregated at the tips of stems and branches. Perianth is (2.3)2.8-4.7 (5) $\mathrm{mm}$ long, 1.8-2.8 times as long as wide, the tube is (15) $20-37 \%$ of the perianth length, tepals are laterally overlapping, outer 3 tepals are oblong, flat but becoming cucullate in fruit, green with pink, red or white margins; tepal veins are branched and thickened; stamens 7-8. Achenes are brown to dark brown, trigonous, ovate, (2.1)2.7-3.7 mm, enclosed in perianth or with apex barely visible at maturity (achene edges are not visible), faces subequal, concave, stri- ate-tubercled*, apex straight; late-season achenes are uncommon.

II. Polygonum aviculare subsp. buxiforme-Plants are graygreen or blue-green, rarely green, homophyllous to subheterophyllous (almost heterophyllous). Stems are usually numerous, extensively branched, procumbent and matforming, 20-70(200) cm long. Ocreae are 3.5-6.5(8) $\mathrm{mm}$ long with the free part silvery, relatively persistent, with inconspicuous veins and after disintegrating leaving almost no fibrous remains. Leaf blades are green or gray-green, lanceolate, elliptic, oblanceolate, or obovate*, 6-40 $\times$ 3-6(13) mm, 2.5-5.6(10) times longer than wide, apices acute to obtuse. Cymes with 2-6 flowers, which are mostly uniformly distributed, but also present at stem and branch apices. Perianth is (2)2.3-3.4 (-3.6) mm long, 0.9-1.3(1.5) times as long as wide; the tube is $20-36 \%$ of the perianth length; tepals are laterally overlapping, the outer 3 tepals have a broadened, pouched base and cucullate* apices, green with white or sometimes pink borders; tepal veins are branched, moderately to strongly thickened; stamens 7-8. Achenes are light brown to brown, (1.8)2-2.8(3) mm, usually enclosed in the perianth at maturity, faces are subequal, concave to flat, coarsely striate-tubercled* to obscurely tubercled; apex is straight; late-season achenes are common, to $5 \mathrm{~mm}$ long.

III. Polygonum aviculare subsp. neglectum-Plants are green, homophyllous or sometimes heterophyllous. Stems are numerous, slender, flexuous, wiry, procumbent to ascending, sometimes erect, (5)15-60 cm long. Ocreae are (3) 4-8 mm long, with a few inconspicuous veins, eventually disintegrating and leaving few or no fibrous remains. Leaf blades are green, narrow-elliptic or oblanceolate, $8-38 \times$ 1.5-6.8(8) mm, (3.4)4.2-9.2 times as long as wide, apices acute or obtuse. Cymes have 1-3(5) flowers, and are regularly spaced along the stems and branches. Perianth is (1.9)2.3-3.4 mm long, 1.6-2.6 times as long as wide, the tube is $28-48 \%$ the length of the perianth; tepals are initially overlapping, spreading slightly as the achene matures, the outer 3 tepals are oblong, \pm cucullate*, green with pink or red (rarely white) borders; tepal veins are branched, moderately to strongly thickened; stamens 7-8. Achenes are dark brown, 1.2-1.8 $\mathrm{mm}$ long, exserted from the perianth at maturity, faces are unequal or less often subequal, striatetubercled* or rarely obscurely so; the apex has straight edges or it is somewhat bent toward the narrow face; lateseason achenes are uncommon.

IV. Polygonum aviculare subsp. depressum-Plants are green, homophyllous to subheterophyllous. Stems are numerous, prostrate to ascending, branched at most nodes (mat-forming) to $100 \mathrm{~cm}$ long. Ocreae are 3-5.5 mm long, with the free part soon disintegrating and leaving almost no fibrous remains. Leaf blades are green, elliptic to narrowelliptic or oblanceolate, (6.2)8-32 × (1.4)2-7(10) $\mathrm{mm}$, 2.8-5.7(6.5) times as long as wide, apices obtuse or acute. Cymes with 2-7 flowers, uniformly distributed or sometimes crowded toward branch apices. Perianth is 
(1.8)2-3.4(4) mm long, 1.5-2.9 times as long as wide, tube is $40-57 \%$ of the perianth length; tepals are initially overlapping, spreading slightly as the achene matures, outer 3 tepals are oblong, flat or obscurely cucullate* in fruit, green with white margins (which may be brown-reddish in the inner part), midveins are unbranched, thin to moderately thickened; stamens 5-7. Achenes are dark brown, trigonous or sometimes biconvex, 1.5-2.7(3) mm, usually slightly exserted from the perianth at maturity, faces are unequal, flat to concave, almost smooth, roughened, or coarsely striate-tubercled; apex is straight or slightly bent toward the narrow face; late season achenes are common, $4.5 \mathrm{~mm}$ long.

V. Polygonum aviculare subsp. rurivagum-Plants are green, homophyllous to heterophyllous. Stems are 1-10, slender, procumbent to ascending, branched at most nodes, $10-40 \mathrm{~cm}$. Ocreae are (6)8-12 mm long, with the distal part having prominent veins and eventually disintegrating into persistent fibers. Leaf blades are green, narrowly elliptic to linear-lanceolate, (10)15-27(30) $\times$ 0.5-4.8(8) $\mathrm{mm}$, (4.5)5-15(19) times as long as wide, apices acute, lateral veins strongly raised on the lower side of leaf blades. Cymes 1-3-flowered, uniformly distributed along stems and branches. Perianth is $2.2-3.1 \mathrm{~mm}$ long, 1.6-2.6 times as long as wide; tube is $26-40(42) \%$ of perianth length; tepals are \pm cucullate, often not overlapping, green, margins pink or red, midveins are branched, moderately to strongly thickened; stamens 7-8. Achenes are blackish brown, trigonous, 2.1-2.6(3) $\mathrm{mm}$, usually exserted from perianth at maturity, faces subequal or unequal, coarsely striate-tubercled*; apex straight; late season achenes unknown.

VI. Polygonum aviculare subsp. boreale-Plants are green; homophyllous or subheterophyllous. Stems are 1-7, prostrate to ascending, mostly branching from base, 6-50(90) $\mathrm{cm}$. Ocreae are 3.5-7 mm long, with distal part soon disintegrating, nearly completely deciduous. Leaf blades are green, obovate-spathulate* or oblanceolate* (12.5)16-44 $(55) \times(4) 6-18(22) \mathrm{mm}, 2-4(5.5)$ times as long as wide, apices obtuse to rounded. Cymes with (3)4-7-flowered, uniformly distributed, rarely crowded at tips of stems and branches. Perianth is 3.3-5.5 mm long, 1.6-2.8 times as long as wide; tube is $25-35(39) \%$ of perianth length; tepals are obovate*, flat or curved outward in fruit, overlapping, green, margins white or pink, midveins branched, thickened; stamens 6-8. Achenes are dark brown, (2.5)2.74(4.2) $\mathrm{mm}$ long, enclosed in perianth at maturity, faces subequal, concave, coarsely striate-tubercled*, apex straight; late season are achenes uncommon.

(d) Illustrations-Polygonum aviculare illustrated in some largely used weed manuals is in fact $P$. aviculare subsp. depressum (= P. arenastrum) (e.g., Alex 1992; Uva et al. 1997; Holm et al. 1997). Illustrations of "Polygonum arenastrum" from some recent weed manuals (e.g., Royer and Dickinson 1999; Bubar et al. 2000) are P. aviculare subsp. aviculare. Line drawings of the four subspecies (mature plant, flowers and fruits) can be found in Karlsson (2000). See Fig. 1 for illustrations of plants at seedling and adult stages, and Fig. 2 for the morphology of perianth at the fruiting stage.

\section{Economic importance}

(a) Detrimental-Polygonum aviculare in Canada is mostly known as a nuisance weed of lawns, sidewalks and paved areas (Alex 1992), and large sums are spent annually to control it (P. Cavers, personal communication). There are no reports regarding its effects on crops from North America. Crop losses associated with $P$. aviculare were reported in Europe for beans (Phaseolus vulgaris L.) (MontenegroGálvez and Criollo-Escobar 1978; Qasem 1995), peas (Pisum sativum L.) (Wright and Baloch 1999), corn (Zea mays L.) (Bulcke et al. 1987) wheat (Triticum aestivum L.) (Catullo et al. 1983), safflower (Carthamus tinctorius L.) (Paolini et al. 1998), and pastures (López and Mattiacci 1983). The economic impact of $P$. aviculare was evaluated in Australia, where P. aviculare was one of the major weeds identified in an annual winter-cropping system (Jones et al. 2000). Maximum yield loss coefficients varied from 0.04 to 0.06 depending on the crop and the density of $P$. aviculare plants (see Jones et al. 2000 for methodology).

Glycosides, long-chain fatty acids (Alsaadawi and Rice 1982a, b; Alsaadawi et al. 1983), phenolic compounds, linolenic and oxalic acids (Kim et al. 1995) from the living plants and/or the residues and soil inhibited the germination and/or growth of Medicago polymorpha L. (Lovett 1986), M. sativa L. (Chung et al. 1994), lettuce (Lactuca sativa L.) and rice (Oryza sativa L.) (Kim et al. 1995). Some of the allelopathic substances identified had an inhibitory role over different strains of Rhizobium and Azotobacter (Alsaadawi and Rice 1982a; Alsaadawi et al 1983). Due to its long and procumbent stems, it affected mechanical harvesting of onions (Allium cepa L.) and carrots (Daucus carota L.) in England (Knott 1990). Ingestion of Polygonum aviculare has been suspected of causing nitrite poisoning and death of horses in Australia (Knight 1979).

(b) Beneficial-Polygonum aviculare is an ancient medicinal plant (see section 6). According to the literature reviewed by Duke (1985), it was classified as "anodyne, antiperiodic, antiseptic, astringent, cholagogue, demulcent, diuretic, emetic, emollient, expectorant, hemostat, laxative, tonic, vasoconstricting, vermifuge, and vulnerary". The herb has beneficial effects against cardiovascular problems, infections (Tunon et al. 1995) and immunity deficiencies (Plachcinska et al. 1984; Stajner et al. 1997). Consequently, the herb is one of the commercial ingredients in products such as Padma Basic, Adaptrin or Reatival (R), created to treat related afflictions. The extract of $P$. aviculare was tested with good results against gingivitis (Gonzalez Begne et al. 2001). The methanol extract has been shown to prevent the liver fibrosis associated with hepatitis C (Nan et al. 2000). Polygonum aviculare is an ingredient in a Himalayan herbal mixture that was clinically tested with good results in Canada and the United States for the treatment of diarrhea in dogs and cats (Silver, unpublished). It contains general antimicrobial chemicals (Cowan 1999), glycosides, flavonoids, mucopolysaccharides (Wren 1992; Kim et al. 1994; Vysochina 1999; Smolarz 2002), 


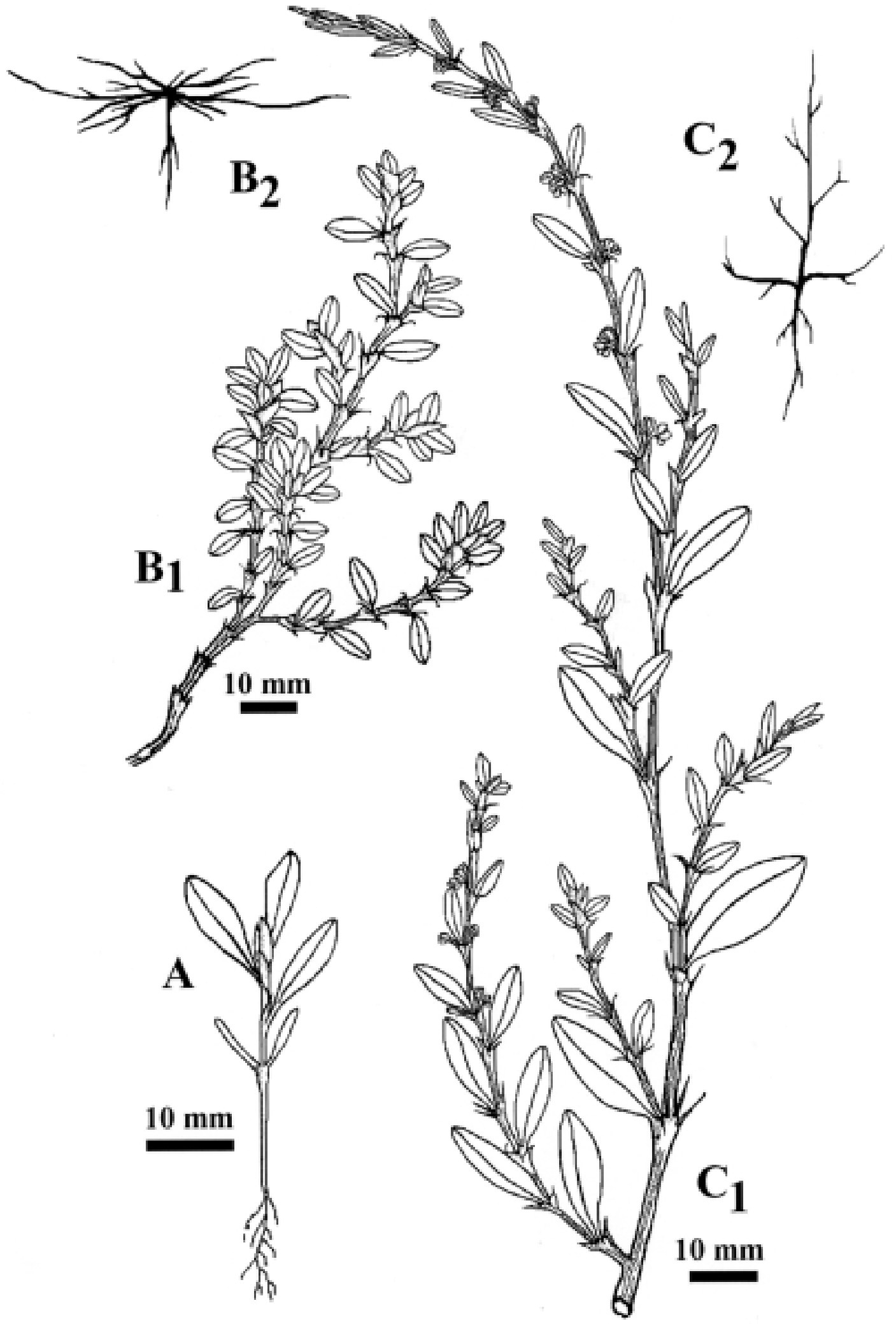

Fig. 1. A. Seedling of Polygonum aviculare subsp. aviculare. B. Polygonum aviculare subsp. depressum: B1. Fragment of plant, B2. schematic representation of habit. C. Polygonum aviculare subsp. aviculare: C1. Fragment of plant, C2 schematic representation of habit. 

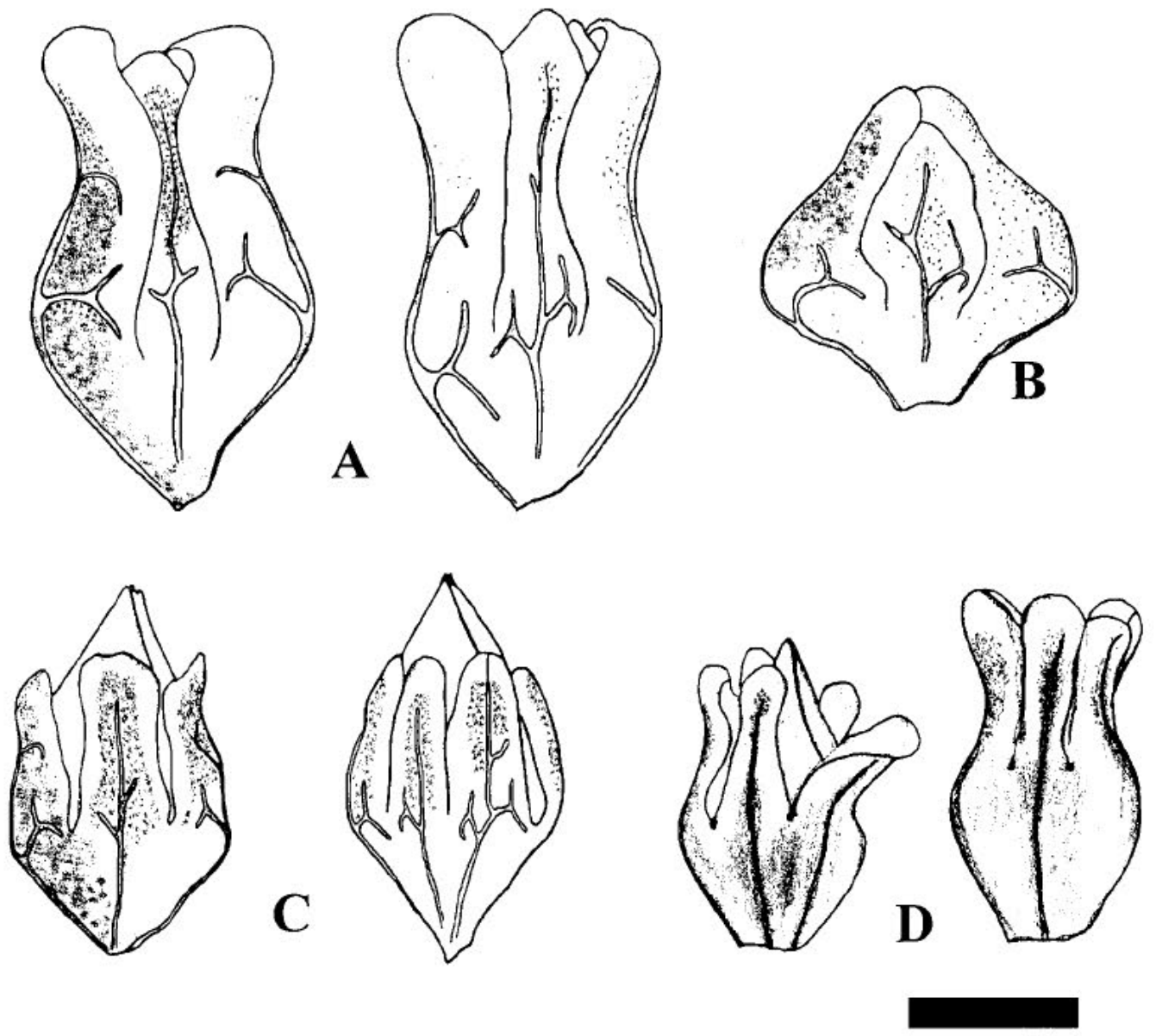

Fig. 2. Achenes with their enclosing perianths. A. Polygonum aviculare subsp. aviculare, B. P. aviculare subsp. buxiforme, C. P. aviculare subsp. neglectum, D. P. aviculare subsp. depressum (scale bar $=1 \mathrm{~mm})$.

naphtoquinones (Al-Hazimi and Haque 2002), 1\% silicic acid, phenol-carboxylic acids, coumarin derivatives including umbelliferone and scopoletin (Bisset and Wichtl 2001), and numerous minerals (Popov 1994). The extract of P. aviculare has fungicidal and bactericidal effects (Sas-Piotrowska and Piotrowski 1997a, b; Maoz and Neeman 1998).

Young shoots and leaves are consumed in China as a "famine food" (Read 1946; Baranov 1967). Polygonum aviculare is used to make a tea known as Weidermannscher or Homeriana tea and it has been used as a substitute for "ergot" in Russia (Duke 1985). Casquero et al. (1993) suggested that $P$. aviculare could be used for fodder because plants contain high amounts of amino acids and minerals. Piglets fed with a supplemented mixture containing leaves of $P$. aviculare had the best gain in weight and efficiency of food utilization (Grela et al. 2003). Fresh flowering stems of $P$. aviculare may be used as a dye for various textiles; resulting colors vary from intense yellow to green-tan and green-beige (McGuffin 1986). Because it quickly covers bare soil, it slows down or prevents erosion to some extent (P. Cavers, personal communication). In Australia, flowers are visited by bees and produce moderate amounts of honey especially after heavy summer rains (Goodman, ed. 1973 in Lamp and Collet 1989). (c) Legislation-In Canada, $P$. aviculare is listed as a noxious weed only in Québec, (Anonymous 2004a).

\section{Geographical Distribution}

Polygonum aviculare is probably one of the most widespread weeds in the world (Coquillat 1951; Holm et al. 1997; Meerts 2002). The distribution of $P$. aviculare subspecies in Canada is based on herbarium specimens from A, ACAD, ALTA, CAS, DAO, DC, DS, GH, F, JEPS, LL, MT, MTMG, NFLD, NSPM, NY, PO, QFA, QUE, RSA, SASK, TEX, UBC, UC and US.

I. Polygonum aviculare subsp. aviculare is common in all provinces and all territories except Nunavut (Fig. 3).

II. Polygonum aviculare subsp. buxiforme has been collected from all the provinces and territories except, Nunavut, Newfoundland and Labrador (Fig. 4). It is especially frequent in southwestern Manitoba, Saskatchewan, Alberta and southern British Columbia.

III. Polygonum aviculare subsp. neglectum occurs in the southern parts of British Columbia, Alberta, Saskatchewan, Manitoba, Ontario and Québec, as well as in Newfoundland, New Brunswick, Nova Scotia and Prince Edward Island (Fig. 5). It is particularly common in southern Ontario and Québec. 


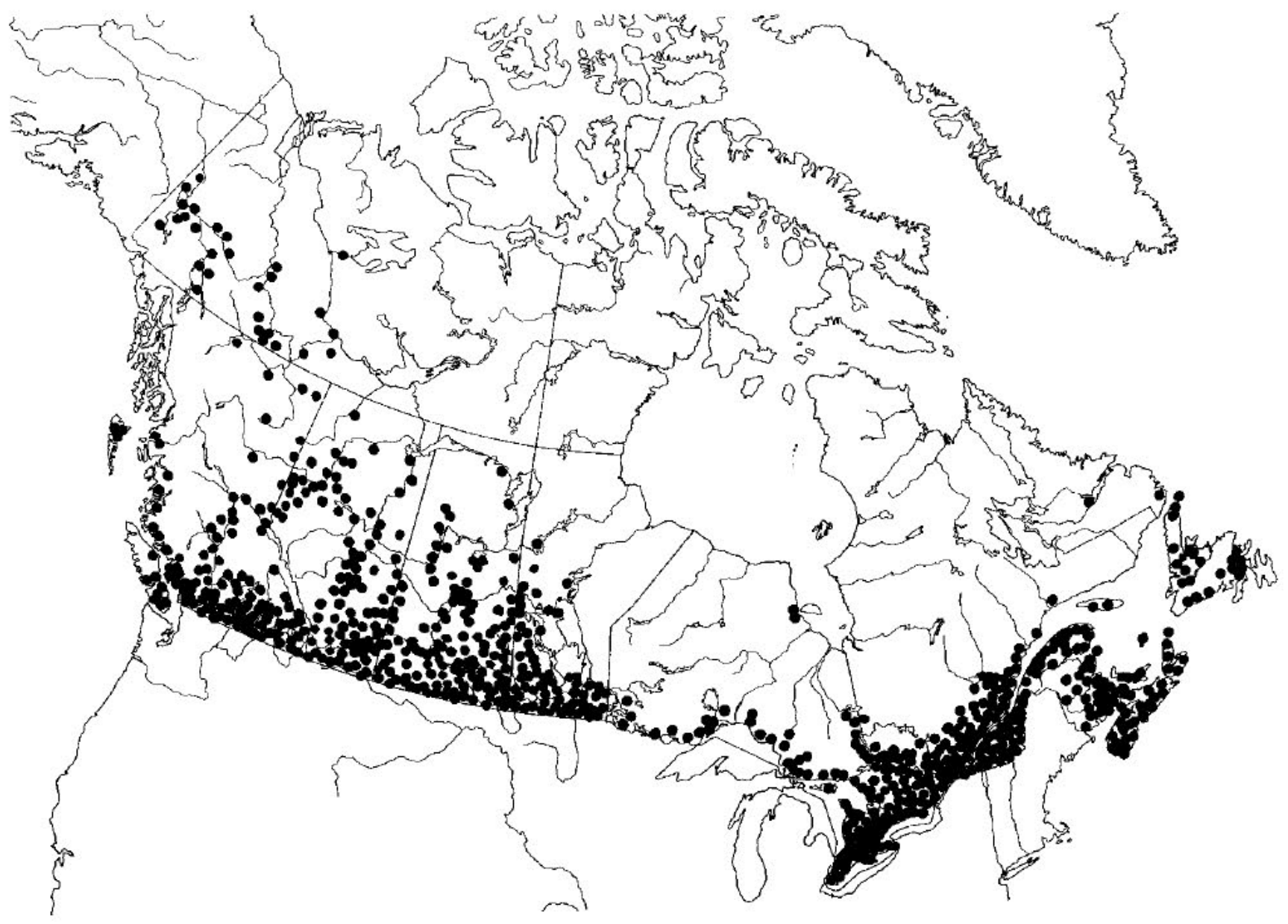

Fig. 3. Distribution of Polygonum aviculare subsp. aviculare in Canada.

IV. Polygonum aviculare subsp. depressum occurs in all Canadian provinces and territories, except the Yukon and Nunavut (Fig. 6). The collections from British Columbia, Alberta and Manitoba are rather scarce suggesting a lower frequency in these provinces. This subspecies is common in southern Ontario and Québec, New Brunswick and Nova Scotia.

\section{Habitat}

(a) Climatic requirements-Polygonum aviculare is found in an extremely wide array of climates, from subtropical to subarctic (Costea, unpublished). There are no data available on the climatic limitations of the subspecies. Apparently in North America, $P$. aviculare subsp. aviculare and $P$. aviculare subsp. buxiforme are found in the widest range of climates, followed by $P$. aviculare subsp. depressum. Based on herbarium data, the former two subspecies may occur in ruderal communities up to $3500 \mathrm{~m}$ elevation in temperate regions.

(b) Substratum-Polygonum aviculare grows well in soils that are compacted, poorly aerated and poor to rich in nutrients. However, the weed surveys undertaken in Saskatchewan have shown that $P$. aviculare was common on all the types of soils and textures (Thomas and Wise 1983b, 1986b, 1987, 1989). The highest frequencies and relative abundances in this province were recorded on the Dark Brown Chernozem and Brown Chernozem soils. Polygonum aviculare was recorded to grow on detritus calcareous deposits, with $\mathrm{CaCO}_{3}$ contents ranging from 35 to $49 \%$ (Kutyna 1998). The species can tolerate drought, low soil fertility (Grime et al. 1988), temporary flooding (Tsuruuchi 1986), high salt content (St.-Arnaud and Viceent 1988; Foderaro and Ungar 1997; Khan and Ungar 1998), and heavy metal contamination (Rutkowska and Stypinski 1997). Polygonum aviculare is a neutrophyle; it grows on substrates with $\mathrm{pH}$ varying from 5 to 8.4 (Lefevre 1956; Grime et al. 1988).

(c) Communities in which species occur-Polygonum aviculare is commonly considered a weed of spring cereals and turf (e.g., Hanf 1983; Tottman and Wilson 1990; Turgeon et al. 1994), but as a world-wide pest it has been recorded in approximately 60 crops (Meerts 2002). The species occurs in Canada in most crops (e.g., cereals, corn, soybeans, canola, rape, sunflower, flax, sugarbeet, vegetable crops, turf and pas- 


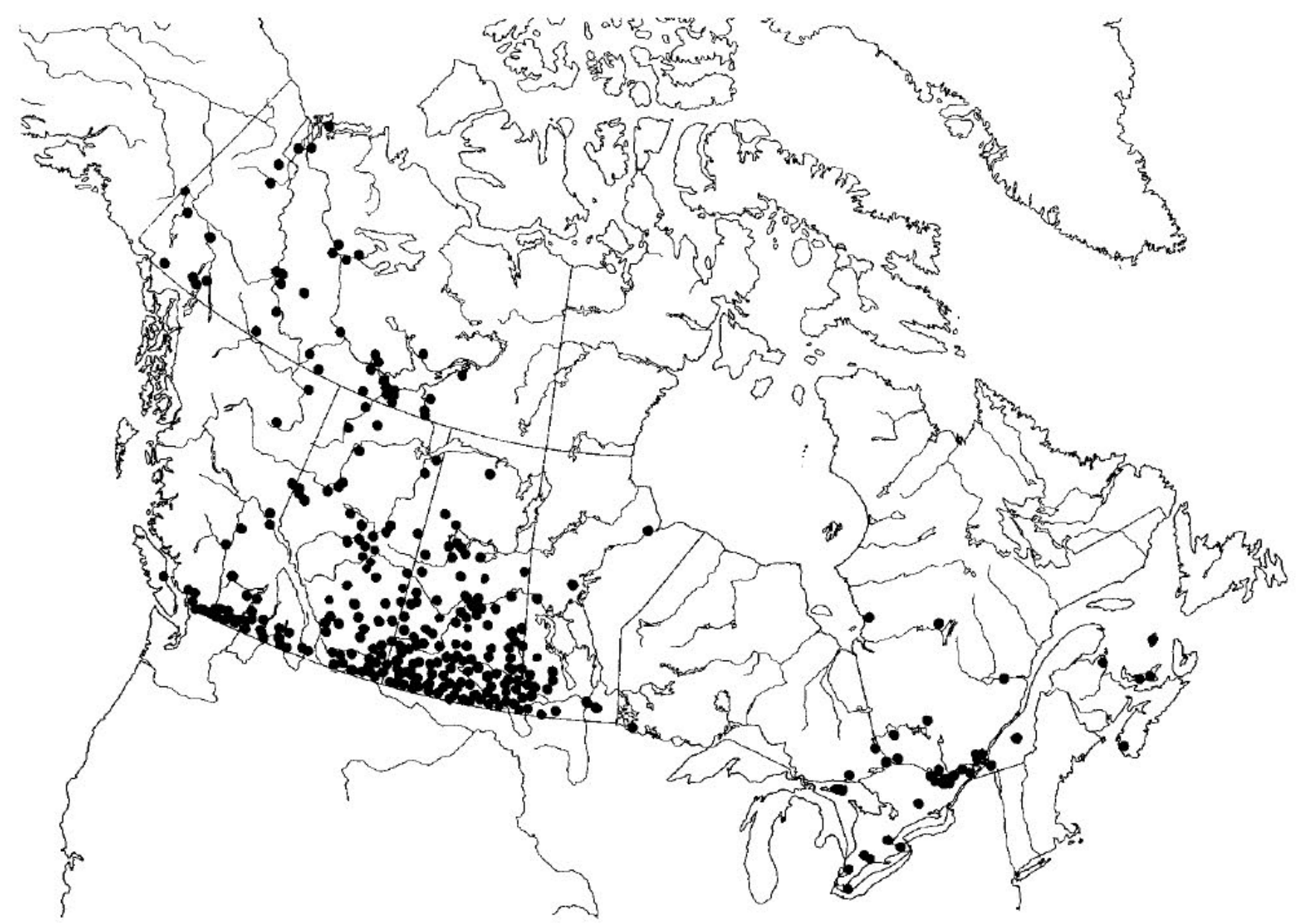

Fig. 4. Distribution of Polygonum aviculare subsp. buxiforme in Canada.

tures, orchards, tree nurseries and vineyards) (Table 2), as well as in ruderal habitats (disturbed ground, along roadsides and railways, waste land, rubbish tips, fallow fields). The Canadian weed survey conducted between 1922 and 1944 and based on 4686 survey lists of settled regions, provided the first data on the occurrence and frequency of $P$. aviculare in Canada (Table 1) (Groh and Frankton 1949). The relatively high frequency values were calculated as the number of lists in which a particular species was recorded out of every 100 survey lists (Table 1). The species has usually been ranked among the top 25 to 50 weed species in most of the weed surveys undertaken in Canada (Table 2).

Dale and Thomas (1987) described weed communities of cereal and oilseed crops in Saskatchewan using data from surveys of more than 400 fields. Cluster analysis grouped $P$. aviculare on the same dendrogram branch with (listed in decreasing order of similarity measures): Echinochloa crusgalli (L.) Beauv., Hordeum jubatum L., Artemisia biennis Willd., Amaranthus blitoides S. Wats., Euphorbia serpyllifolia Pers., Lepidium densiflorum Schrad. and Kochia scoparia (L.) Schrad. Polygonum aviculare is a characteristic species for vegetal communities of trampled environments and field margins (Kress 1988; Wilson and Aebischer
1995). The species can be found in all tillage systems. Its density appears to be influenced more by weed management practices and crop rotational sequences than by tillage system (Frick et al. 1990; Hallgren 1996; Bàrberi et al. 1997; Dorado et al. 1997; Bàrberi et al. 2001).

Polygonum aviculare also occurs as urban weed in "moderately heavy foot- or wheel- traffic where the soils may be low in fertility and so heavily compacted that other plants are unable to survive. It is one of the most common weeds along roadsides edges of or cracks in sidewalks and pavement, and heavy-traffic areas in lawns" (Alex 1992). In a band within 50 $\mathrm{cm}$ of heavily used sidewalks at the University of Western Ontario, the two species comprising over $75 \%$ of the vegetative cover were $P$. aviculare and Plantago major L. (both subsp. major and subsp. pleiosperma Pilger)(P. Cavers, personal communication). Other species in Canada growing in such environments are: Eleusine indica (L.) Gaertn., Echinochloa crus-galli (L.) Beauv., Digitaria sanguinalis (L.) Scop., Setaria pumila (Poir.) Roem. \& Schult., Panicum dichotomiflorum Michx., P capillare L., Poa annua L., Chaenorrhinum minus (L.) Lange, Chamaesyce spp., Matricaria matricarioides (Less.) Porter., Plantago spp., Polygonum achoreum Blake., and Sagina procumbens L. (Costea, personal observation). 


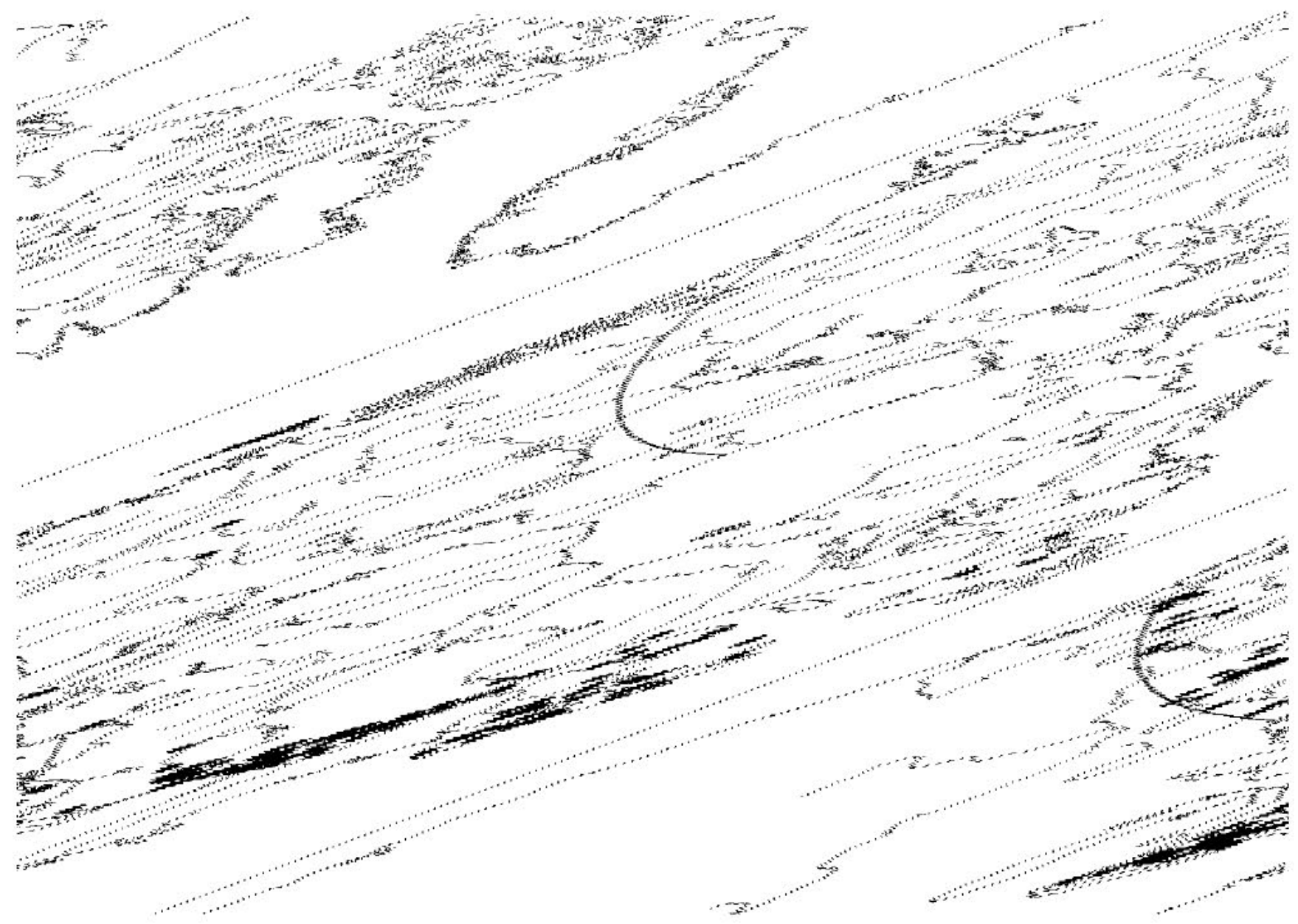

Fig. 5. Distribution of Polygonum aviculare subsp. neglectum in Canada.

\section{History}

The presence of $P$. aviculare pollen in deposits from Europe is considered an indicator of human impact during the Holocene (Leeuwen et al. 1988; O'Connell and Molloy 2001). The species has been know from antiquity. The name "Polygonum" was first used by Dioscorides ("Polygon", see Gunther 1959) and then by Pliny the Elder (Historia Naturalia, Book 26: 115-119, 1951) referring-judging on their descriptions - to one member of the $P$. aviculare complex. Both Dioscorides (see Gunther 1959) and Pliny in the first century $\mathrm{AD}$, accurately described some of the medicinal properties of the knotweed mentioned in section $2 \mathrm{~b}$. For example, Dioscorides stated: "being sodden with wine \& withall taking honey, it doth excellent well for the ulcers [...]. The leaves are laid on for ye burning of ye stomach \& ye casting up of blood \& inflammations \& wounds newly made". Gerard (1975) mentioned other uses: "It is given to swine with good successe when they are sicke and will not eat their meate, whereupon the country people so call it Swine's Grass and Swine's Skir". Other medicinal uses were mentioned by Markham (1994): "To cure the worst bloody flux that may be, take a quart of red wine, and a spoonful of Cummin seed. Boyl them together until half be consumed, then take knot-grass, and Shepherde- purse, and Plantane, and stamp them severall, and then strain them, and take the juice of each... a good spoonful; and put them to the wine, and so seeth them again a little; then drink it lukewarm, half over night, and half the next morning". Fuchs (1999) observed its ecology: " $P$. mas... grows everywhere and is daily trampled upon, growing by waysides and footpaths" (De historia stipium, p. 613). From an esoteric perspective, Heinrich Cornelius Agrippa (1651) examining "the things (that) are under the Signs, the fixed Stars, and their Images" quoted Apuleius in associating the knotweed with the sun (Of Occult Philosophy, Book I, part 2).

An English medieval superstition, beautifully illustrated by Shakespeare (1924), said that the infusion made from knotweed's stems and leaves would stunt the growth of a boy or of a young animal (Midsummer Night's Dream, III., 2: "Get you gone, you dwarf;/You minumus, of hindering knot-grass made"). Because of this propriety, the plant was ideal in the business of burglaries. In Beaumont and Fletcher's (1969), “The Coxcomb”, Dorothy tells the Tinker: "We want a boy extremely for this function, kept under for a year with milk and knot grass".

Polygonum aviculare was probably mentioned for the first time in North America by Cornuti (1966) in 


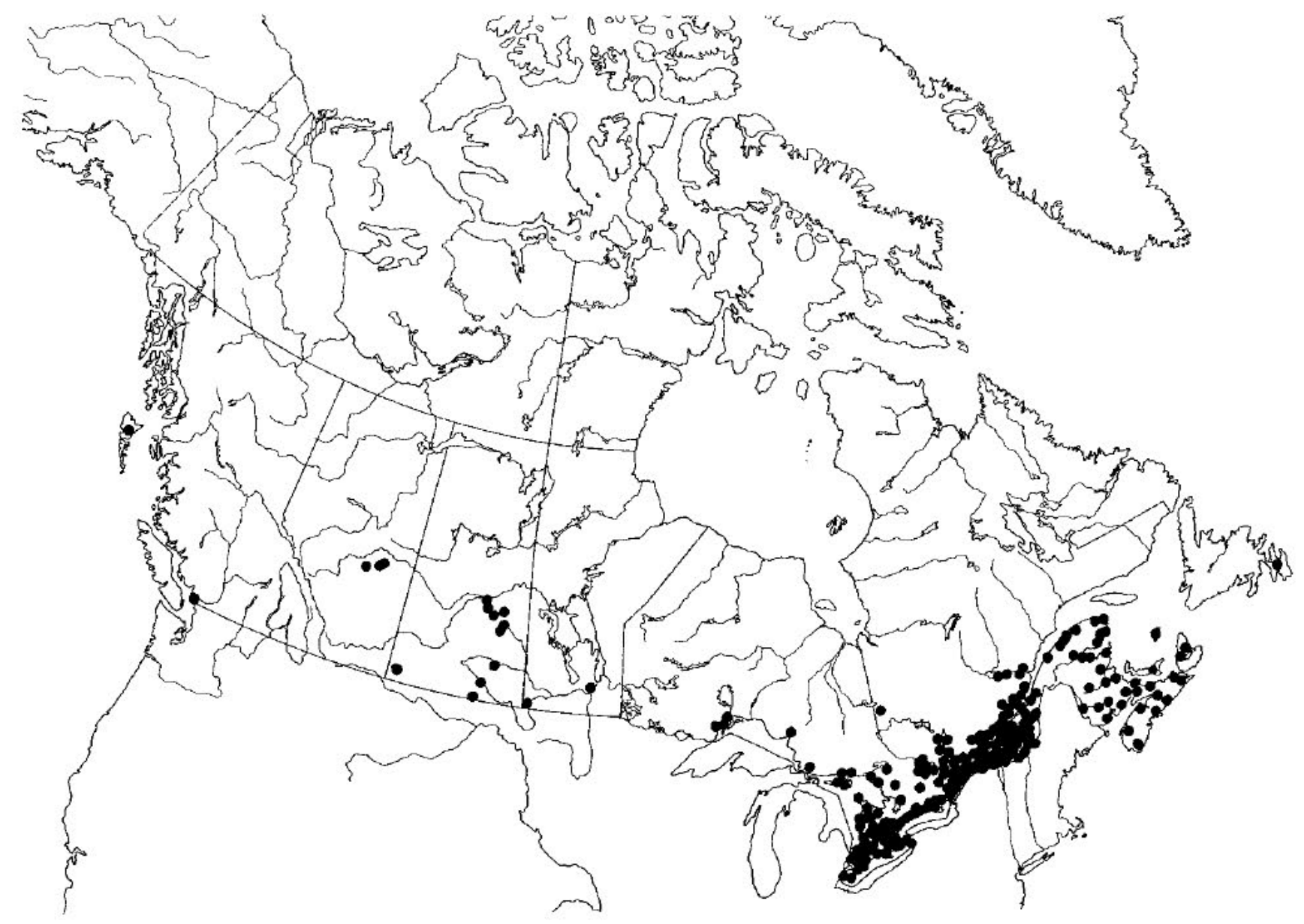

Fig. 6. Distribution of Polygonum aviculare subsp. depressum in Canada.

Canadensium Plantarum (1635), "per margines viarum". Gronovius (1762) also mentioned it in Flora Virginica. As with many other common European weeds, it was probably introduced in North America by the first colonists (Stuckey and Barkley 1993). In Canada, it was first collected by A. Holmes from Montreal in 1821, growing in ruderal places, gardens, railroads (Rousseau 1968). Clark and Fletcher (1909), in "Farm weeds of Canada" wrote (that P. aviculare " accompanies civilized man everywhere (...), and it is found along roads and trails forming mats (...)." The distribution ranges, particularly of $P$. aviculare subsp. depressum, are likely to continue to expand in the future.

\section{Growth and Development}

(a) Morphology-The growth habit is indeterminate and the overall plant architecture of $P$. aviculare agg. is extremely variable, depending on both genetic and environmental factors. In most cases, plants show various degrees of resistance to trampling, which are associated with different phenotypes and life strategies (see below). Plants have the capacity to regenerate from axillary buds if the apex is removed (Salisbury 1961).

The development of $P$. aviculare is based exclusively on apical and axillary meristems, because quiescent meristems are absent (Geber 1989). Apical meristems determine the vegetative $(\mathrm{V})$, monopodial growth of the stem and shoots. Axillary meristems differentiate either as new vegetative elements (higher order of branches) or as reproductive (R) structures (inflorescences). Apical dominance plays a significant role in the architecture of $P$. aviculare. Repeated removal (twice) of the apical meristems resulted in increased branching and a trend towards reduced fitness (McPhee et al. 1997). The vegetative (V) and reproductive (R) types of development of the axillary meristems are mutually exclusive and they are negatively correlated genetically (Geber 1990). This necessary trade-off has been interpreted as a result of resource limitation or simply as a meristematic limitation (Geber 1990). Vegetative and reproductive growth overlap throughout the life history of plants. Although $\mathrm{V}$ growth is preponderant in young plants, floral structures start to develop very early, from the 4th to 6th nodes (Geber 1990). Gradually, more and more axillary meristems switch from $\mathrm{V}$ growth to flowering, which eventually becomes dominant. Based on the variable ontogenetic ratios between $\mathrm{V}$ and $\mathrm{R}$ growth, a continuum of different genetically fixed life strategies with different morphologies can evolve at the population or intrapopulation level. Two 
Table 1. Frequency (\%) of Polygonum aviculare in different longitudinal areas of Canada between 1922 and $1944($ Groh and Frankton 1949). BC = British Columbia, $\mathbf{A B}=$ Alberta, $\mathrm{SK}=$ Saskatchewan, $\mathrm{MB}=$ Manitoba, $\mathrm{ON}=$ Ontario, $\mathrm{QC}=$ Québec; $\mathrm{w}=$ western, $\mathrm{e}=$ eastern, $\mathrm{nw}=\mathrm{northwestern}$

\begin{tabular}{|c|c|c|c|c|c|c|c|c|}
\hline Area of Canada & $\begin{array}{l}131-116^{\circ} \mathrm{W} \\
\mathrm{BC} \& \mathrm{~W} \mathrm{AB}\end{array}$ & $\begin{array}{c}115-108^{\circ} \mathrm{W} \\
\text { e } \mathrm{AB} \& \text { w SK }\end{array}$ & $\begin{array}{c}107-100^{\circ} \mathrm{W} \\
\text { SK \& w MB }\end{array}$ & $\begin{array}{c}99-92^{\circ} \mathrm{W} \\
\text { e } \mathrm{MB} \& \text { w ON }\end{array}$ & $\begin{array}{c}91-84^{\circ} \mathrm{W} \\
\text { Superior ON }\end{array}$ & $\begin{array}{c}83-76^{\circ} \mathrm{W} \\
\text { Central ON } \\
\& \text { nw QC }\end{array}$ & $\begin{array}{c}75-68^{\circ} \mathrm{W} \\
\text { e ON \& } \\
\text { Central QC }\end{array}$ & $\begin{array}{c}67-60^{\circ} \mathrm{W} \\
\text { Maritimes \& } \\
\text { Gaspé }\end{array}$ \\
\hline Survey (No.) & 713 & 364 & 427 & 192 & 117 & 947 & 921 & 1005 \\
\hline $\begin{array}{l}\text { P. aviculare } \\
\text { Frequency (\%) }\end{array}$ & 56.6 & 59 & 48.2 & 43.7 & 37.6 & 42.3 & 50.0 & 27.0 \\
\hline
\end{tabular}

Table 2. Frequency, density and relative abundance of Polygonum aviculare from weed surveys across Canada. Relative abundance is a combination of the frequency, field uniformity (all fields) and mean field density (all fields) (see any of the cited weed surveys for more information). The rank (importance) relative to other species encountered in the surveys, is based on frequency, density, relative abundance and other quantitative variables. Most surveys were conducted in the summer after herbicide treatment. " $x$ " - species not recorded in the survey; "-" data not available. In Ontario: (1) Essex and Kent Counties; in Québec: (1) Region of Québec; (2) Cantons-de-l'Est; (3) Region of Richelieu; (4) South West of Montreal; (5) L'Asomption

\begin{tabular}{|c|c|c|c|c|c|c|c|}
\hline Province & Crop(s) & Year & $\begin{array}{c}\text { Frequency } \\
(\%)\end{array}$ & 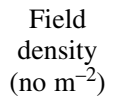 & $\begin{array}{c}\text { Relative } \\
\text { abundance }\end{array}$ & Rank & Source \\
\hline British & Wheat & 1978-1980 & 8.3 & 1.3 & 1.2 & 31 & Thomas and Wise (1983a) \\
\hline \multirow{3}{*}{ Columbia } & Barley & 1978-1980 & 6.0 & 0.9 & 0.9 & 33 & Thomas and Wise (1983a) \\
\hline & Oats & 1978-1980 & 5.3 & 1.2 & 0.8 & 37 & Thomas and Wise (1983a) \\
\hline & Rape & 1978-1980 & 5.8 & 7.4 & 1.5 & 29 & Thomas and Wise (1983a) \\
\hline \multirow{10}{*}{ Alberta } & Wheat, barley, oats, rapeseed, flax & 1973-1977 & 0.6 & 1.8 & 0.11 & 41 & Thomas and Wise (1985) \\
\hline & Spring wheat & 1997 & 1.6 & 0.5 & 0.4 & 42 & Thomas et al. (1998) \\
\hline & Spring wheat & 2001 & 2.2 & 2.8 & 1.3 & 30 & Leeson et al. (2001) \\
\hline & Barley & 1997 & 1.4 & 0.7 & 0.3 & 46 & Thomas et al. (1998) \\
\hline & Barley & 2001 & 0.6 & 28.3 & 0.7 & 39 & Leeson et al. (2001) \\
\hline & Oat & 1997 & 2.8 & 6.6 & 1.3 & 31 & Thomas et al. (1998) \\
\hline & Oat & 2001 & 1.2 & 0.6 & 0.2 & 55 & Leeson et al. (2001) \\
\hline & Canola & 1985 & 1.9 & 0.4 & 0.4 & 47 & Thomas et al. (1986) \\
\hline & Canola & 1997 & 1.8 & 0.5 & 0.1 & 47 & Thomas et al. (1998) \\
\hline & Canola & 2001 & 3.2 & 2.0 & 1.2 & 28 & Leeson et al. (2001) \\
\hline \multirow[t]{25}{*}{ Saskatchewan } & Wheat, barley, oats, flax, rape, rye & 1976 & $\mathrm{x}$ & $\mathrm{x}$ & 1.6 & 30 & Thomas (1977) \\
\hline & Wheat, barley, oats, flax, rape, rye & 1977 & 6.3 & 1.6 & 1.3 & 30 & Thomas (1977) \\
\hline & Wheat, barley, oats, flax, rape, rye & 1978 & 5.2 & 0.8 & 1.3 & 33 & Thomas (1978a) \\
\hline & Wheat, barley, oats, flax, rape, rye & 1979 & 4.8 & 1.1 & 1.1 & 28 & Thomas (1979) \\
\hline & Spring wheat/durum & $1976-1979$ & 5.3 & 1.7 & 1.3 & 26 & Thomas and Wise (1983b) \\
\hline & Spring wheat & 1995 & 3.9 & 2.3 & 1.3 & 31 & Thomas et al. (1996) \\
\hline & Winter wheat & 1985 & 0.7 & 1.3 & 1.8 & 30 & Thomas and Wise (1986b) \\
\hline & Winter wheat & 1986 & 2.3 & 1.3 & 0.7 & 38 & Thomas and Wise (1987) \\
\hline & Winter wheat & 1985-1988 & 2.9 & 1.0 & 0.9 & 38 & Thomas and Wise (1989) \\
\hline & Durum wheat & 1995 & 1.2 & 3.3 & 0.7 & 39 & Thomas et al. (1996) \\
\hline & Barley & 1976-1979 & 4.7 & 1.6 & 1.1 & 33 & Thomas and Wise (1983b) \\
\hline & Barley & 1986 & 1.7 & 4.3 & 0.5 & 42 & Thomas and Wise (1987) \\
\hline & Barley & 1995 & 3.7 & 1.6 & 1.1 & 32 & Thomas et al. (1996) \\
\hline & Oats & $1976-1979$ & 8.2 & 7.5 & 2.1 & 25 & Thomas and Wise (1983b) \\
\hline & Fall rye & 1976-1979 & 10.5 & 1.1 & 1.6 & 24 & Thomas and Wise (1983b) \\
\hline & Flax & 1976-1979 & 2.7 & 0.7 & 0.6 & 42 & Thomas and Wise (1983b) \\
\hline & Flax & 1986 & 3.7 & 0.2 & 0.8 & 34 & Thomas and Wise (1987) \\
\hline & Flax & 1995 & 3.8 & 0.5 & 0.7 & 36 & Thomas et al. (1996) \\
\hline & Rape & $1976-1979$ & 6.1 & 1.3 & 1.4 & 27 & Thomas and Wise (1983b) \\
\hline & Lentil & 1985 & 3.6 & 0.9 & 0.9 & 24 & Douglas and Thomas (1986) \\
\hline & Lentil, field pea & 1995 & 5.3 & 0.8 & 1.2 & 31 & Thomas et al. (1996) \\
\hline & Canola & 1986 & 3.0 & 0.7 & 0.8 & 35 & Thomas and Wise (1987) \\
\hline & Canola & 1995 & 1.9 & 0.4 & 0.4 & 48 & Thomas et al. (1996) \\
\hline & Mustard & 1985 & 10.3 & 0.6 & 1.8 & 23 & Douglas and Thomas (1986) \\
\hline & Sunflower & 1985 & 2.0 & 0.2 & 0.3 & 43 & Thomas and Wise (1986a) \\
\hline \multirow[t]{10}{*}{ Manitoba } & Wheat, barley, oats, flax, rape & 1978 & 7.7 & 2.2 & 1.6 & 23 & Thomas (1978b) \\
\hline & Wheat & 1986 & 2.7 & 0.5 & 0.5 & 38 & Thomas and Wise (1988) \\
\hline & Spring wheat & 1997 & 4.3 & 3.2 & 1.3 & 25 & Thomas et al. (1998) \\
\hline & Spring wheat & 2002 & 2.4 & 1.1 & 0.8 & 29 & Leeson et al. (2002) \\
\hline & Barley & 1986 & 1.8 & 0.5 & 0.4 & 45 & Thomas and Wise (1988) \\
\hline & Barley & 1997 & 2.8 & 1.5 & 0.9 & 28 & Thomas et al. (1998) \\
\hline & Barley & 2002 & 2.5 & 0.4 & 0.6 & 30 & Leeson et al. (2002) \\
\hline & Oat & 1986 & 4.0 & 1.2 & 0.8 & 33 & Thomas and Wise (1988) \\
\hline & Oat & 2002 & 4.5 & 0.5 & 1.0 & 30 & Leeson et al. (2002) \\
\hline & Flax & 1986 & 3.3 & 0.3 & 0.6 & 29 & Thomas and Wise (1988) \\
\hline
\end{tabular}




\begin{tabular}{|c|c|c|c|c|c|c|c|}
\hline & Flax & 1997 & 9.1 & 0.4 & 1.6 & 24 & Thomas et al. (1998) \\
\hline & Flax & 2002 & 2.7 & 4.4 & 1.5 & 26 & Leeson et al. (2002) \\
\hline & Canola & 1986 & - & - & - & - & Thomas and Wise (1988) \\
\hline & Canola & 1997 & 4.6 & 0.7 & 1.0 & 30 & Thomas et al. (1998) \\
\hline & Canola & 2002 & 3.9 & 0.9 & 1.3 & 29 & Leeson et al. (2002) \\
\hline \multirow[t]{2}{*}{ Ontario } & Tomato & 1960-1961 & 14.5 & - & - & 37 & Alex (1964) \\
\hline & Corn & $1960-1961$ & 14.5 & - & - & 37 & Alex (1964) \\
\hline \multirow[t]{2}{*}{ (1) } & Corn & 1978-1979 & 2.5 & 1.5 & 0.6 & 30 & Hamill et al. (1983) \\
\hline & Corn & 1988-1989 & 4.0 & 1.4 & 1.6 & 29 & Frick et al. (1990) \\
\hline \multirow[t]{2}{*}{ (1) } & Soybean & $1978-1979$ & 0.9 & 0.2 & 0.1 & 36 & Hamill et al. (1983) \\
\hline & Soybean & 1988-1989 & 7.2 & 0.6 & 2.4 & 25 & Frick et al. (1990) \\
\hline \multirow[t]{2}{*}{ (1) } & Cereals & 1978-1979 & 4.7 & 5.6 & 3.0 & 15 & Hamill et al. (1983) \\
\hline & Wheat & 1988-1989 & 17.9 & 1.3 & 5.1 & 14 & Frick et al. (1990) \\
\hline \multirow[t]{3}{*}{ Québec (1) } & Corn & 1980 & 31.6 & - & - & - & Doyon et al. (1986) \\
\hline & Sweet corn & 1980 & 11.1 & - & - & - & Doyon et al. (1986) \\
\hline & Strawberry & 1980 & 25.9 & - & - & - & Doyon et al. (1986) \\
\hline \multirow[t]{3}{*}{ (2) } & Corn & 1980 & 20.8 & - & - & - & Doyon et al. (1987a) \\
\hline & Cereals & 1981 & 55.6 & - & - & - & Doyon et al. (1987a) \\
\hline & Strawberry & 1981 & 31.0 & - & - & - & Doyon et al. (1987a) \\
\hline \multirow[t]{11}{*}{ (3) } & Cereals & 1982 & 37.1 & - & - & - & Doyon et al. (1987b) \\
\hline & Sugarbeet & 1982 & 28.2 & - & - & - & Doyon et al. (1987b) \\
\hline & Sugarbeet & 1983 & 66.7 & - & - & - & Doyon et al. (1987b) \\
\hline & Strawberry & 1982 & 25.5 & - & - & - & Doyon et al. (1987b) \\
\hline & Strawberry & 1983 & 60.0 & - & - & - & Doyon et al. (1987b) \\
\hline & Cereals & 1983 & 70.7 & - & - & - & Doyon et al. (1987b) \\
\hline & Corn & 1983 & 52.8 & - & - & - & Doyon et al. (1987b) \\
\hline & Soybeans & 1983 & 33.3 & - & - & - & Doyon et al. (1987b) \\
\hline & Winter wheat & 1983 & 100 & - & - & - & Doyon et al. (1987b) \\
\hline & Alfalfa & 1983 & 66.7 & - & - & - & Doyon et al. (1987b) \\
\hline & Carrots & 1983 & 25.0 & - & - & - & Doyon et al. (1987b) \\
\hline \multirow[t]{10}{*}{ (4) } & Cereals & 1981 & 48.6 & - & - & - & Doyon et al. (1987c) \\
\hline & Cereals & 1982 & 68.4 & - & - & - & Doyon et al. (1987c) \\
\hline & Corn & 1981 & 16.9 & - & - & - & Doyon et al. (1987c) \\
\hline & Corn & 1982 & 32.7 & - & - & - & Doyon et al. (1987c) \\
\hline & Soybeans & 1981 & 25 & - & - & - & Doyon et al. (1987c) \\
\hline & Strawberry & 1981 & 77.7 & - & - & - & Doyon et al. (1987c) \\
\hline & Strawberry & 1982 & 64.7 & - & - & - & Doyon et al. (1987c) \\
\hline & Carrots & 1982 & 37.0 & - & - & - & Doyon et al. (1987c) \\
\hline & Onion & 1982 & 28.6 & - & - & - & Doyon et al. (1987c) \\
\hline & Potatoes & 1982 & 66.6 & - & - & - & Doyon et al. (1987c) \\
\hline \multirow{7}{*}{50} & Cereals & 1983 & 61.2 & - & - & - & Doyon et al. (1987d) \\
\hline & Corn & 1983 & 58.7 & - & - & - & Doyon et al. (1987d) \\
\hline & Potatoes & 1983 & 22.2 & - & - & - & Doyon et al. (1987d) \\
\hline & Tomatoes & 1983 & 14.3 & - & - & - & Doyon et al. (1987d) \\
\hline & Strawberry & 1983 & 63.3 & - & - & - & Doyon et al. (1987d) \\
\hline & Carrots & 1983 & 33.3 & - & - & - & Doyon et al. (1987d) \\
\hline & Rye & 1983 & 77.1 & - & - & - & Doyon et al. (1987d) \\
\hline \multirow[t]{2}{*}{ Island } & Wheat, oats, barley & 1978 & $\mathrm{X}$ & $\mathrm{x}$ & 0.6 & 38 & Ivany (1980) \\
\hline & Wheat, oats, barley & 1979 & $\mathrm{x}$ & $\mathrm{x}$ & 0.9 & 42 & Ivany and Thomas (1983) \\
\hline New Brunswick & Cereals & $1986-1987$ & 2.1 & - & - & - & Thomas et al. (1994) \\
\hline
\end{tabular}

divergent life histories, which are separated by a range of intermediates, may be distinguished both in European and North American populations of P. aviculare (Geber 1990; Meerts 1992):

(i) The "hasty opportunist" ("r"-strategist, Begon et al. 1996) has an early meristematic commitment to reproduction, which determines an early fecundity at the cost of reduced vegetative growth. Such plants are smaller and less branched, their phenology is accelerated, the life-span shortened and the reproductive output reduced.

(ii) The "persevering hard worker" ("K"-strategist, Begon et al. 1996) has prolonged V growth, which results in larger and more branched plants that flower later, live longer, and produce more fruits.

Meerts (1992) found that these two contrasting life strategies in $P$. aviculare subsp. aviculare were associated with the level of ploidy: the short-lived genotypes were tetraploid, while the long-lasting genotypes were hexaploid. The capacity for life history specialization among the genotypes of the $P$. aviculare complex explains in part the high colonizing capacity of this species. Populations with contrasting life strategies can occupy temporally separated niches (Meerts 1992), or they can constitute a back-up strategy for years when bad conditions occur early in the summer or late in the season (Geber 1990). 
Meerts and Garnier (1996) analyzed the growth of 12 genotypes from three contrasting regimes of disturbance: trampled areas, weedy populations and no-disturbance conditions. There was significant genotypic variation in relative growth rate $\left(0.355-0.452 \mathrm{~g} \mathrm{~g}^{-1} \mathrm{~d}^{-1}\right)$, which was positively correlated with leaf area and achene size (Meerts and Garnier 1996). However, other experiments showed that infraspecific plasticity, characteristic of $P$. aviculare agg., is not necessarily genetically differentiated (Meerts and Vekemans 1991). Populations from heavily trampled conditions had up to five times shorter internodes, shorter but more numerous secondary branches, smaller and narrower leaves, and up to $33 \%$ greater allocation to $\mathrm{R}$ growth. They produced up to three times more seeds than populations from untrampled conditions (Meerts and Vekemans 1991). Additionally, soil fertility and moisture may determine a wide range of phenotypic modifications (Meerts 1995).

The dimorphic summer and autumn achenes enable the polymorphism in dormancy, germination and early plant growth (see section 8b). The pericarp structure, especially in summer fruits, ensures optimal dispersal by water, animals and birds (see section $8 b$ ).

Anatomical data (Small 1895; Metcalfe and Chalk 1950; Sokolova and Bogdanova 1966; Haraldson 1978; Kutschera and Sobotik 1992; Watson and Dallwitz 1992-onwards)The primary root has 3-7 xylem bundles in the central cylinder. Stems do not usually have periderm. Collenchyma is distributed in ridges or arranged in semicircles, chlorenchyma is well-developed and the endodermis is distinct. The fibrous schlerenchyma is discontinuous and organized in strands on the inner part of the endodermis. The secondary xylem has solitary or clustered vessels, up to $60 \mu \mathrm{m}$ in diameter, with vestured pits*. The sieve tube plastids belong to the S-type*. Leaves have a dorsiventral structure and anisocitic* stomata. The minor leaf veins have no phloem transfer cells.

Embryological data-The gynoecium is usually threecarpelled, syncarpous* and one-celled, or sometimes one carpel may be reduced. The three (or sometimes two) styles are fused at the base, and the stigmas are capitate*. The ovule is single, orthotropous*, bitegmic* and crassinucellate* (Johri et al. 1992). The inner integuments form the micropyle. The funiculus is short and placentation is basal. The embryo-sac is of the Polygonum-type with ephemeral antipods* (Johri et al. 1992). The "seeds" of Polygonum spp. are actually achenes (fruits) in which the hard pericarp (developed from carpels) is fused with the thin seed coat resulting from the ovule's integuments. The mature embryo is erect, comma-like and extends along one of the achene's ribs. The endosperm is nuclear and consists of two regions: a peripheral aleurone layer and the inner endosperm, with simple and compound starch grains (Woodcock 1914; Lonay 1922; Johri et al. 1992; Yurtseva et al. 1999; Yurtseva 2001).

(b) Perennation-The species is annual and relies on seeds for overwinter survival. (c) Physiological data-Geber and Dawson (1990) studied genetic variation in leaf gas-exchange physiology in $P$. aviculare subsp. depressum. The authors found significant differences between different genotypes in photosynthetic carbon assimilation rate (A), leaf conductance to water vapor (g), instantaneous water-use efficiency (WUE), and leaf carbonisotope discrimination $(\Delta)$. The mentioned characteristics varied as follow: $\mathrm{A}_{\max }=13.92-19.52 \mu \mathrm{mol} \mathrm{CO} \mathrm{m}^{-2} \mathrm{~s}^{-1} ; \mathrm{g}_{\max }=$ $0.32-0.54 \mathrm{~mol} \mathrm{H}_{2} \mathrm{O} \mathrm{m}^{-2} \mathrm{~s}^{-1}$; WUE $=0.78-0.98 \mathrm{mmol} \mathrm{CO}_{2}$ $\mathrm{mol}^{-1} \mathrm{H}_{2} \mathrm{O} ; \Delta(\%)=20.07-21.17$. In addition, stomatal and biochemical traits were also genetically variable (Geber and Dawson 1997). Strong genetic correlations were observed between the maximum amounts of ribulose 1,5-biphosphate carboxylase-oxygenase (Rubisco) and the electron transport capacity, and between the latter and stomatal conductance. The genotypes of the "hasty opportunist" with smaller leaves tended to have higher gas exchange rates and a lower wateruse efficiency than the long-lived genotypes. The differences among genotypes in photosynthesis are the result of multiple changes that occur both in biochemical and stomatal characteristics. Physiological variation is correlated with morphological plasticity.

(d) Phenology —As already shown, $P$. aviculare agg. plants have mechanisms that ensure a polymorphism of germination and variable growth and development rates, which have direct consequences on phenology. However, some general characteristics may be recognized. In the southern part of Canada, most $P$. aviculare seeds become non-dormant in March-April and germinate in a single flush between March and May (during cold springs the interval may be extended until the beginning of June). Chepil (1946) in Swift Current, Saskatchewan noted that the germination of $P$. aviculare in the field occurred between Apr. 23 and May 15. Germination of $P$. aviculare seeds in a single flush was also observed in Kentucky (between March and April; Baskin and Baskin 1990), the United Kingdom (from late February to late May; Courtney 1968) and Argentina (between August and November; Kruk and Benech-Arnold 1998). Although the germination of $P$. aviculare is concentrated during a narrow window of opportunity in spring, a lower number of seeds can germinate during the summer in Europe (Witts 1960; Courtney 1968; Roberts and Feast 1970; Froud-Williams et al. 1984) and autumn in Canada (personal observation). Plants resulting from seeds that germinate in autumn produce few or no seeds. In Russia, the larger late-autumn achenes germinate $2(-3)$ wk earlier than the summer ones (Yurtseva et al 1999). Plants need $30-45 \mathrm{~d}$ to initiate flowering and the first seeds are shed approximately 2 mo after seedling emergence (personal observation). The length of the life cycle is different from genotype to genotype: in some, senescence may occur only 1 mo after flowering has begun; in others, flowering and setting fruits overlap until late autumn when plants are killed by frost (November). Between these two contrasting life strategies, populations with a range of intermediate characteristics may occur (see section 7a).

(e) Mycorrhiza-The presence of mycorrhiza in Polygonum aviculare agg. is controversial. Some authors reported the 
occurrence of vesicular arbuscular mycorrhiza, while others did not find any mychorrizal association (Harley and Harley 1987; Kasowska 2002). According to Reeves et al. (1979), plants in disturbed habitats are non-mychorrizal, while in natural habitats more than $99 \%$ of the plants are mychorrizal. Mychorrizas (VA and ectomychorriza) have been documented in other Polygonum sensu lato species (reviewed by Harley and Harley 1987; Massicotte et al. 1998; Titus and Tsuyuzaki 2002).

\section{Reproduction}

(a) Floral biology-The synflorescence in Polygonum is a spiciform* foliate thyrse*, in which the axillary monochasial* cymes belong to the scorpioid* type (Cialdella 1992). Each cyme is partially enclosed by the ocrea of the neighboring leaf or bract. Additionally, each flower within the cymes is protected by a smaller ocrea (ocreole); the youngest flowers being totally enclosed by the concentrically imbricated ocreoles (Cialdella 1992). The flowering in the thyrse starts from the base (acropetalous). Within each cyme, flowering starts with the flower developed in the vicinity of the main axis and proceeds successively with new flowers, which are initiated in alternating directions.

Flowers are hermaphroditic. Chasmogamous (flowers that open) and cleistogamous (flowers that remain closed) flowers may occur on the same plant and in the same cyme (Yurtseva 1998). Both types of flower share some common characteristics (Laubengayer 1937; Ronse Decraene and Akeroyd 1988; Ronse Decraene and Smets 1991; Yurtseva 1998). Stamens are arranged in two whorls and their number varies from 5 to 8 . Occasionally, the outer whorl is missing. The inner 5 stamens have dilated filaments with flattened bases and are longer than the outer 3 stamens, which have filiform filaments (Ronse Decraene and Akeroyd 1988). Anthers are tetrasporangiate* (with four pollen sacs), small, ovate and open longitudinally. A correlation was sometimes observed between the absence of outer stamens and the number of carpels. For example, $P$. aviculare subsp. depressum has often 5 stamens and a 2carpelled gynoecium. The number of stamens can also vary on the same plant during the vegetation cycle. Yanishevsky (1927) noted that late-summer and autumn flowers had 5 stamens, while early-summer flowers had 8 stamens. The pollen grains at dispersal are three-celled. They are usually tricolporate*, tectate*, subprolate*, with a finely reticulate or tuberculate exine (Wodehouse 1931; Hedberg 1946; Garcia et al. 1998). The well-developed nectaries of other Polygonaceae (e.g., Persicaria, Fagopyrum) are absent from the flowers of $P$. aviculare. However, sections through the inner staminal filaments revealed a nectarial-type tissue: "perhaps a layer of cells at the base of the filaments secretes nectar" (Ronse Decraene and Akeroyd 1988; Ronse Decraene and Smets 1991).

Chasmogamous flowers-In every cyme, usually only one flower opens at a time. Flowering occurs early in the morning and each flower remains open for $1-4 \mathrm{~d}$. The anthers of the inner circle of stamens open first. The dehiscence of all anthers may take $0.5-2 \mathrm{~d}$ depending on environmental con- ditions; with light and dry weather accelerating the process. When the first anthers start to open, the gynoecium is underdeveloped and immersed in the perianth tube, which is filled with nectar. The ovary starts to enlarge only after dehiscence of the anthers reaches the outer circle of stamens. A short gynophore (peduncle) raises the ovary and the stigmas reach the same level as the inner circle of anthers. Self pollination is the result of direct contact between the stigmas and inner anthers. During this phase, entomophilous pollination may occur as well. Bugg et al. (1987) and Yurtseva (1998) observed numerous arthropod species feeding on nectar or floral tissues, and other authors also reported that flowers are frequently visited by insects (Löve and Löve 1956; Goodman (ed.) 1973 in Lamp and Collet 1989; Schmid 1983; Karlsson 2000; Zolda 2001). Morphologically atypical pollen grains of $P$. aviculare were observed in the fecal samples of some hover flies (Diptera: Syrphidae) such as Sphaerophoria scripta L., Syritta pipiens L. and Syrphus ribesii L., as well as in the feces of their bird and bat predators (Binka 2003). The flowers can be considered protandrous although normally a short overlapping period between the male and the female flowering phases occurs. After 1 to $5 \mathrm{~d}$, the flowers (the perianth lobes) close in the evening. The stamens from the outer circle are thus brought into contact with the stigmas and a second opportunity for self-pollination then occurs. Fertilization is porogamous* and the pollen tubes are persistent.

Cleistogamous flowers-In the same cyme, some flowers remain closed, and pollination occurs under the protection of the perianth. Cleistogamous flowers have a longer perianth tube than chasmogamous flowers, while the perianth lobes are about the same length (Yurtseva 1998). This author observed that a wave of cleistogamous flowers developed in summer, $1 \mathrm{wk}$ after a period of hot and dry weather with temperatures of $30-36^{\circ} \mathrm{C}$. The development of cleistogamous flowers in autumn could not be associated with any specific weather conditions (Yurtseva 1998).

The stamens have a constant filament length in both cleistogamous and chasmogamous flowers, as well as in summer and autumn flowers. However, the styles may have different lengths and therefore the flowers are heterostylous. Nikitina (1965) reported that early-developed flowers have a short style of $0.1 \mathrm{~mm}$, while late flowers have a longer style of 0.4 $\mathrm{mm}$. The capitate stigma is larger in late-summer and autumn-developed flowers than in early-summer flowers (Yanishevsky 1927). Yurtseva (1998) found rare situations when among chasmogamous flowers of the same age, some had longer styles and the stigmas exceeded the anthers. The same feature, constantly expressed this time, was observed in cleistogamous flowers (Yurtseva 1998).

Most authors have considered $P$. aviculare and related taxa to be self-pollinated (e.g., Scholz 1958; Styles 1962; Meerts et al. 1998). Indeed, the inconspicuous inflorescences with flowers partially hidden in the ocreae and the reduction of floral nectaries seem to indicate an evolutionary tendency in this direction. Yurtseva (1998) reported that emasculated chasmogamous flowers did not produce fruits. However, the floral dimorphism present in $P$. aviculare agg. 
is difficult to explain in view of the autogamy reported for these plants. Structures that make cross-pollination possible in other Polygonum sensu lato are preserved in P. aviculare and there are numerous reports of flowers visited by insects (Löve and Löve 1956; Schmid 1983; Karlsson 2000). Cleistogamous and chasmogamous flowers, heterostyly, protandry and the capacity to secrete nectar may be regarded as remnants of an ancestral mixed-mating system (Costea and Tardif, unpublished).

(b) Seed production and dispersal - A single plant may produce from 125-200 (Hanf 1983) to 6400 achenes (Stevens 1932) depending on the availability of resources and competition (Zwerger 1990; Meerts 1995). Achenes have an average weight of $0.003 \mathrm{~g}$ (P. aviculare subsp. aviculare) or $0.002 \mathrm{~g}$ (P. aviculare subsp. rurivagum) (Salisbury 1961). The dispersal of achenes can be accomplished in various ways: through farm machinery, by birds and animals after ingestion, and by water. Seeds are easily carried in the footwear of tire treads, and since plants are resistant to trampling they can develop anywhere along machinery pathways. Seeds may occur as impurities in harvested crops or as contaminants of seeds to be sown (Salisbury 1961; Hill et al. 1999; Sahadeva 2001; Meerts 2002). At least some seeds are not damaged after they are ingested and excreted by animals (sheep, cattle and horses) and birds (Salisbury 1961; Ozer and Hasimoglu 1977; Grime et al. 1988; Holmes and Froud-Williams 2001). The seeds float both when separated or enclosed in the persistent perianth and they can be dispersed through irrigation water, in streamlets produced on the soil by rain and by water courses (Salisbury 1961; Tosso et al. 1986; Holm et al. 1997).

Many plants of $P$. aviculare exhibit a unique form of heterocarpy in which two different types of achenes develop on the same plant at different ages (Wolf and McNeill 1986).

Summer achenes-These fruits develop from early flowers. They are small compared to autumn achenes and have a darkbrown pericarp. The exocarp is $30-60 \mu \mathrm{m}$ thick, with the outer cell-walls provided with longitudinal rows of papillae or tubercles. The papillae are about $15 \mu \mathrm{m}$ in diameter and may play a role in imbibition. Exocarp cell-walls are heavily thickened following a peculiar pattern. As a result, the mature exocarp cell-lumen appears dendritically (tree-like) branched. Mesocarp cell-walls are suberinised (Yurtseva et al. 1999; Ronse Decraene et al. 2000; Yurtseva 2001).

Autumn achenes-These fruits develop from late summer and autumn flowers, have a green-olivaceous pericarp and are up to two or three times longer than the summer fruits. Their exocarp is about $20 \mu \mathrm{m}$ thick, with smooth external periclinal walls. The exocarp cell-wall is thinner and the cell-lumen is not branched. The mesocarp contains chloroplasts that produce assimilates that are allocated to the seeds for a month. In general, the structure of the autumn fruits' exocarp resembles that of immature summer achenes. Their seeds have a longer embryo and a more developed endosperm than seeds of summer achenes (Yurtseva et al. 1999). Taking into account the structure of the inflorescence in $P$. aviculare, autumn fruits are likely to be found in the upper part of the shoots and on the first order axes within each axillary cyme. The ontogenetic heterocarpy in $P$. aviculare has biological and ecological significance (see section 7a).

(c) Seed banks, seed viability and germination-Polygonum aviculare has a persistent seed bank, in which a cyclical dormancy/non-dormancy pattern is undergone by the seeds in the soil (Roberts 1981; reviewed by Baskin and Baskin 1998; see below). In Swift Current, Saskatchewan, Chepil (1946) found that although a significant proportion of the $P$. aviculare seeds germinated in the year after they were produced, a smaller number of seedlings emerged in the field 3 to $5 \mathrm{yr}$ after sowing, depending on the soil type. Four and two seedlings (from 1000 seeds sown in the field) emerged after $4 \mathrm{yr}$ in clay and sandy loam soils, respectively, and two seedlings emerged after $5 \mathrm{yr}$ in a loam soil (Chepil 1946). Survival of $P$. aviculare seeds has been studied since 1984 in Fairbanks, Alaska as part of a 50-yr study. Viability of seeds declined with time: it was $57 \%$ after 9 mo, $31 \%$ after $21 \mathrm{mo}, 7 \%$ after $4.7 \mathrm{yr}$, and $<1 \%$ after $9.7 \mathrm{yr}$ (Conn and Farris 1987; Conn 1990; Conn and Deck 1995). Lutman et al. (2002), in a 6-yr study done in the United Kingdom, reported that $77.2 \%$ of the $P$. aviculare seeds survived each year. The number of years necessary for at least a $95 \%$ decline was estimated to be 9 on a site with loam soil, and 20 on a site with clay soil (Lutman et al. 2002). According to other authors, viable seeds of $P$. aviculare were recovered after as many as $60 \mathrm{yr}$ (Brenchley 1918 cited by Cousens and Mortimer 1995; Campagna and Rapparini 1997). Depth of burial (2 and $15 \mathrm{~cm}$ ) (Conn and Farris 1987) and the groundwater level (Bekker et al. 1998) did not influence the viability of seeds.

Polygonum aviculare has not been evaluated as one of the contributor species to the seed banks of agricultural fields in North America. However, in Spain, Dorado et al. (1999) reported up to 12241 seeds $\mathrm{m}^{-2}$ and a relative abundance of $37.29 \%$, values which placed $P$. aviculare in second place after Amaranthus albus $\mathrm{L}$. The species was also ranked among the six most abundant species in soil seed banks in the United Kingdom (Warwick 1984; Roberts and Chancellor 1986; Grundy et al. 1996; Turley et al. 1998; Thompson et al. 1996; Younie et al. 2002) and Turkey (Coruh and Zengin 2001). More commonly, densities of 200-5000 seeds $\mathrm{m}^{-2}$ and contributions of $0.1-3 \%$ to the total seed bank have been reported in France and Italy (Dessaint et al. 1997; Bàrberi et al. 1998a, b; Bàrberi and Lo Cascio 2001).

Dorado et al. (1999) described the weed seed bank response to crop rotation and tillage in semi-arid agroecosystems from Spain. Under a conventional tillage system, $P$. aviculare exhibited a slightly greater number of seeds in

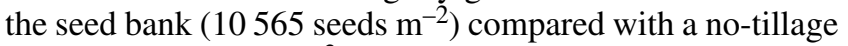
system $\left(8644\right.$ seeds $\left.\mathrm{m}^{-2}\right)$. Similar relative abundances in the seed bank of $P$. aviculare under conventional tillage were reported by Bàrberi et al. (1988b) and Bàrberi and Lo Cascio (2001). With regard to crop rotations, Dorado et al (1999) found that the number of $P$. aviculare seeds in the seed bank was greater in a barley-vetch $\left(12241\right.$ seeds $\left.\mathrm{m}^{-2}\right)$

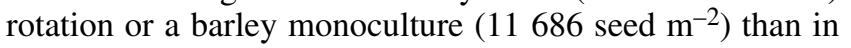


a barley-sunflower rotation (4947 seeds $\mathrm{m}^{-2}$ ). Bárberi et al. (1998a) described the changes in the seed bank under different systems after $5 \mathrm{yr}$ of continuous maize cropping. Although, in general, the weed seed bank was largest under the organic system (100761 seeds $\left.\mathrm{m}^{-2}\right), P$. aviculare scored the highest values under the conventional system $(0.5 \%$ of total seeds in the $0-10 \mathrm{~cm}$ and $10-20 \mathrm{~cm}$ soil layers). Both in reduced-input and strip-cultivation systems, the relative density of $P$. aviculare in the seed bank was higher, 1.5 and $1.3 \%$, respectively, in the $10-20 \mathrm{~cm}$ deep layer of soil.

Most seedlings of $P$. aviculare emerge from the top $3 \mathrm{~cm}$ of soil, and total emergence declines with increasing depth of burial (Froud-Williams et al. 1984; Grundy et al. 1996). The average percentage of the seed bank that emerges as seedlings each year (the emergence percentage) across the Corn Belt of the United States of America was estimated at $0.6 \%$ (Forcella et al. 1997), somewhat higher than the emergence percentage $(0.18 \%)$ reported from Italy (Miele et al. 2000).

The two morphologic types of achenes (see section $8 \mathrm{~b}$ ) are fundamentally different in their dormancy and biology of germination. However, most studies on germination make no mention of the type of achene used in the study. As a result, the role of heterocarpy in the biology of $P$. aviculare is virtually unexplored. The following differences between summer and autumn fruits are based on a single study (Yurtseva et al. 1999) and our personal observations (Costea and Tardif, unpublished). The autumn elongated achenes possess a weak innate dormancy and are capable of germinating immediately after they are produced if they are exposed to temperatures of $20-25^{\circ} \mathrm{C}$. If temperatures are lower, they will germinate the following spring in a single flush, at temperatures as low as $5^{\circ} \mathrm{C}$. The smaller summer achenes have a strong primary dormancy and they may constitute a persistent seed bank. Most of the germination studies undertaken with $P$. aviculare probably refer to this type of achene. Summer achenes undergo a cyclical dormancy/non-dormancy pattern in the soil (Courtney 1968; Baskin and Baskin 1990). Freshly developed summer achenes of $P$. aviculare require a moist chilling treatment at $1.6-12^{\circ} \mathrm{C}$ for $12-110 \mathrm{~d}$ to overcome dormancy (Ransom 1935; Justice 1941; Hammerton 1964; Courtney 1968; Baskin and Baskin 1990; Kruk and Benech-Arnold 1998; Batlla and Benech-Arnold 2003). Cool stratification temperatures administered over a long period of time determined a lower temperature limit for germination (Batlla and Benech-Arnold 2003). Variability in the stratification requirement in various populations of $P$. aviculare was observed by Hammerton (1964) and Courtney (1968). This may be the result of dormancy differences among populations and/or the consequence of using ontogenetically different types of achenes. The lower limit in temperatures necessary for germination in spring of summer achenes $\left(8 \pm 4^{\circ} \mathrm{C}\right.$ ) (Kruk and Benech-Arnold 1998; Yurtseva et al. 1999; Costea and Tardif, unpublished) is higher than that for autumn achenes (5-6 ${ }^{\circ}$ C) (Yurtseva et al. 1999; Costea and Tardif, unpublished).

Baskin and Baskin (1990) reported that $P$. aviculare can germinate at alternating day/night temperatures of up to $35 / 20^{\circ} \mathrm{C}$. Khan and Ungar (1998) obtained a maximum per- centage and rate of germination under light (12-h photoperiod) and $15 / 5^{\circ} \mathrm{C}$. An increase in temperature above this value decreased both the percentage and the rate of germination. Under the same daytime temperature of $25^{\circ} \mathrm{C}$, the percent of germination was higher at a lower nocturnal temperature of $5^{\circ} \mathrm{C}(>70 \%)$ than at $15^{\circ} \mathrm{C}(<50 \%)$ (Khan and Ungar 1998). The required thermal time for germination of $50 \%$ of the nondormant fraction of seeds was 80 degree-days accumulated above a base temperature of $0^{\circ} \mathrm{C}$ (Kruk and Benech-Arnold 1998). Some non-dormant seeds can germinate in darkness, but the germination percentage is higher under light conditions. In Kentucky, non-dormant spring seeds germinated between 90 and $100 \%$ under a photoperiod of $14 \mathrm{~h}$ and 7 to $61 \%$ in darkness (Baskin and Baskin 1990). During early summer, secondary dormancy is enforced in seeds by temperatures of $20^{\circ} \mathrm{C}$ or higher (Courtney 1968; Kruk and Benech-Arnold 1998). Such seeds cannot be germinated in darkness under any temperature. However, summer-exhumed seeds germinated 17 and $53 \%$ in light at $30 / 15$ and $35 / 20^{\circ} \mathrm{C}$, respectively (Baskin and Baskin 1990). Secondary dormancy acquired during summer can be overcome, at least in some seeds, under 24 $\mathrm{h}$ /day light and high temperatures. Mechanical removal of the pericarp or scarification with sulfuric acid improved the germination of $P$. aviculare seeds (Ransom 1935; Justice 1941; Courtney 1968). Germination of $P$. aviculare seeds was not influenced by treatment with a commercially available smokewater solution (Adkins and Peters 2001).

Populations of $P$. aviculare occur in saline sites in North America and an interaction between salinity and temperature was observed in the germination of this species (Foderaro and Ungar 1997; Khan and Ungar 1998). Lower temperatures (e.g., $15 / 5^{\circ} \mathrm{C}$ ) increased the tolerance to salinity, and at such temperatures a small percentage of seeds could germinate, even with $300 \mathrm{mM}$ of $\mathrm{NaCl}$. Treatment with gibberellic acid (GA), $3 \mathrm{mM}$, significantly reduced the secondary dormancy imposed by salinity under all temperature regimes.

(d) Vegetative reproduction-Polygonum aviculare plants do not reproduce vegetatively.

\section{Hybrids}

Although hybridization in $P$. aviculare agg. may be possible, it has never been demonstrated satisfactorily, and artificial hybridization attempts "were not conclusive" (Styles 1962). Nevertheless, because of the many intermediates and overlapping characteristics observed, hybrids were often assumed (e.g., Lindman 1912; Tzvelev 1993; Yurtseva and Kramina 2003). Yurtseva (2001) suggested that patterns of pericarp-surface variation support the hybrid origin of some species. In this respect, $P$. arenastrum presumably originated as a hybrid between $P$. aviculare and $P$. calcatum Lindm. (considered a synonym of $P$. aviculare subsp. depressum in this study) and Polygonum neglectum (= P. aviculare subsp. neglectum) resulted from the hybridization between $P$. aviculare and P. arenastrum (Yurtseva 2001).

\section{Population Dynamics}

Polygonum aviculare may produce a second generation only from the elongated fall achenes (end of August-September), 
although this generation has little chance of completing its life cycle. The species can rapidly colonize trampled environments, including disturbed areas near roads and sidewalks, where it often forms long and narrow or irregular patches. The competitive ability of this species resides in the extreme endurance and adaptability of the plants, multiple possibilities of seed dispersal, a persistent seed bank, high genetic polymorphism, and its allelopathic properties. In such environments, $P$. aviculare was more competitive than many weed species, for example than Polygonum persicaria L., Atriplex patula L. (Harper 1977), Chenopodium album L. and Stellaria media (L.) Vill. (Carver et al. 1997, cited by Meerts 2002). Alsaadawi and Rice (1982a) observed that $P$. aviculare could replace Cynodon dactylon (L.) Pers. growing in pure stands. Furthermore, $P$. aviculare inhibited germination and growth of Chenopodium album, Sorghum bicolor (L.) Moench and Gossypium barbadense L. (Alsaadawi and Rice 1982a). Marshall et al. (2003) in the United Kingdom reported for $P$. aviculare a competitive index of 50 [the number of plants $\left(\mathrm{m}^{-2}\right)$ that gives a $5 \%$ crop yield loss in wheat].

\section{Response to Herbicides and Other Chemicals}

Chemical control of $P$. aviculare in different crops worldwide has been reviewed by Meerts (2002). Polygonum aviculare is susceptible to most soil-applied and foliar (postemergence) herbicides recommended for the control of dicot annual weeds in a range of crops (Anonymous 2002; Marshall et al. 2003). The species was moderately susceptible to MCPA applied at recommended rates in spring barley and to simazine in field beans (Marshall et al. 2003). Polygonum aviculare can also be controlled readily by nonselective herbicides, such as glyphosate, glufosinate, and paraquat (Meerts 2002). There is little evidence of differential response to herbicides among the different subspecies of $P$. aviculare as herbicide labels do not distinguish between them. Chloropicrin, a potential replacement of the soil fumigant methyl bromide, has been reported to be effective at controlling P. aviculare (Haar et al. 2003).

Herbicide Resistance-No herbicide-resistant biotypes have been reported in North America for $P$. aviculare. Biotypes resistant to triazines have been reported from The Netherlands and Poland (Oorschot and Straathof 1988; Lipecki and Szwedo 1988). Biotypes resistant to amitrole were discovered in Belgium (reviewed by Bulcke and Callens 1998). The precise mechanism of resistance for these biotypes is unknown.

\section{Response to Other Human Manipulations}

The subspecies of $P$. aviculare have a wide range of tolerance to trampling. Forms of $P$. aviculare subsp. depressum and subsp. rurivagum are the most resistant to trampling, while those of $P$. aviculare subsp. aviculare are the most susceptible. The other subspecies occupy an intermediate position between these two extremes (Costea, unpublished). Nevertheless, even within each subspecies, the range of tolerance to trampling may vary significantly (Meerts and Vekemans 1991).
Mechanical methods used for the control of $P$. aviculare are usually not efficient alone and they usually are more effective when combined with chemical treatments. Raso et al. (2001) reported that a spring-tined harrow, with one pass at $6 \mathrm{~km} \mathrm{~h}^{-1}$ in an organically grown soft wheat, significantly reduced the total biomass of weeds, among which $P$. aviculare was predominant. Repetition of the treatment did not significantly enhance the weed biomass reduction (Raso et al. 2001). Harrowing in peas (Pisum sativum) provided $85 \%$ control of a weed community dominated by $P$. aviculare and several other weed species, when it was applied once at crop emergence (Rasmussen 1992). Harrowing twice reduced the need for a pre-emergence herbicide treatment, and required only one post-emergence treatment in sugarbeet (Beta vulgaris L.) (Re et al. 1996). Polygonum aviculare was controlled by hoeing, with or without chain harrowing, but chain harrowing alone had limited success (Rafii 1993). Mechanical control with a brush hoe and a spring-tined weeder on May 15 in barley field trials in the United Kingdom did not control P. aviculare (Richards 1991). The disturbance produced by a shallow cultivation reduced the knotweed infestation (Pollard and Cussans 1981; Fernandez -Quintanilla et al. 1984).

Soil solarization with clear or colored polyethylene controlled $P$. aviculare and other weed species in Spain and China (Zhang et al. 1992; Dalmau et al. 1993). In contrast, bark mulching favored $P$. aviculare in apple orchards in Poland (Scibisz et al. 1995). Flaming and hot-steaming did not control $P$. aviculare in apple orchards in Nova Scotia and Slovakia (Rifai et al. 2001).

Hartl (1989) reported that undersowing wheat with Medicago lupulina $\mathrm{L}$. and Trifolium resupinatum $\mathrm{L}$. reduced the dry mass of $P$. aviculare and other weeds by $44-49 \%$, while the grain yield was not affected. The use of domestic White China geese was ineffective for the control of $P$. aviculare and Matricaria matricarioides (Less. ) Porter because these plants were unpalatable and grazing and geese trampling increased their density by 25 times (Wurtz 1995).

\section{Response to Herbivory, Disease and Higher Plant Parasites}

(a) Mammals-Milton et al. (1997) studied the effects of small-scale animal disturbances on plant communities from Germany. Polygonum aviculare plants predominated on patches of soil grubbed by wild boars (Sus scrofa L.).

(b) Birds and/other vertebrates-Polygonum aviculare seeds are among those preferred by many bird species (Wilson et al. 1999; Wilson 2001; Holmes and FroudWilliams 2001). Some authors have suggested that the decline of weed species such as $P$. aviculare has probably contributed to the decline of granivorous birds in European farmland (Wilson 2001; Firbank and Smart 2002). In order to protect bird populations, it was suggested that it would be beneficial to maintain 6-m-wide buffer areas, which would receive no pesticides, around crop fields (Sotherton 1990).

(c) Insects-Information regarding insects associated with $P$. aviculare in North America is scarce and most of the 
studies have been undertaken in Europe, Asia, New Zealand and Australia [e.g., Nadasy 1983; Chu et al. 1983; Hostounsky 1984; Farrell and Stufkens 1993; Gomez de Aizpurua 1994; Ohta et al. 1998; Scott and Yeoh 1998; Every and Stufkens 1999; Meerts 2002 (review)]. Bugg et al. (1987) presented a list of 36 species from Northern California that had been observed to feed at the flowers of $P$. aviculare. Among these, 29 were useful entomophagous species (such as those from the genus Geocoris, Hemiptera: Lygaeidae), which were using the nectar of $P$. aviculare as a complementary food source. Polygonum aviculare is a host of beetles from the genus Mantura Steph. (Coleoptera: Chrysomelidae: Alticinae) from the Palearctic (Heikertinger 1951). Marshall et al. (2003) reported that $P$. aviculare and Poa annua L. were more important than other weeds for maintaining the biodiversity of insects and farmland birds. They suggested that these weed species should be tolerated in order to achieve a sustainable ecological balance.

Pest insects associated with $P$. aviculare in North America include the common housefly (Musca domestica L.), a bulbfly (Eumerus spp.) and a plant bug (Lygus spp.) (Bugg et al. 1987).

Watson et al. (2003) in Berkshire, UK, reported that postdispersal predation of $P$. aviculare seeds was highest in May (92.9\%) followed by a gradual decline to zero values in September. Seeds were predated by small mammals (e.g., wood mouse, Apodemus sylvaticus L.) and invertebrates (e.g., carabid beetles) (Watson et al. 2003). In contrast, Trefas et al. (2001) in Hungary, found that predation of $P$. aviculare seeds by Pterostichus melanarius Illiger was highest in autumn. Gastroidea polygoni Gruev \& Tomov was observed to feed abundantly on $P$. aviculare plants in the United Kingdom, Italy and Turkey, and it was suggested as a potential biocontrol agent for this weed (Sotherton 1982; Marocchi 1994; Kismali and Madanlar 1990). Another potential biocontrol agent, Entomoscelis orientalis Motschulsky, has been proposed in China (Hu et al. 1989).

(d) Nematodes-Polygonum aviculare in Canada has been reported as a host of Meloidogyne hapla Chitwood in Ontario (Townshend and Davidson 1962). In North America it has been identified as a host of Ditylenchus dipsaci Filipjev in Illinois (Edwards and Taylor 1963), Meloidoderita spp. in Maryland (Andrews et al. 1981), and Meloidogyne incognita (Kofoit and White) Chitwood in Indiana (Gaskin 1958). In Europe, it was reported as a host of Ditylenchus dipsaci (Anguillulina dipsaci Kuhn) the United Kingdom (Bendixen et al. 1979; Atkinson and Sykes 1981) and in Yugoslavia (Vlk and Holubcova 1972); Heterodera schachtii Schmidt in Spain (López and Romero 1988); Meloidogyne spp. in Germany (Bendixen et al. 1979) and Pratylenchus penetrans (Cobb) Chitwood \& Oteifa in Spain (Abrantes et al. 1987). Polygonum aviculare was among the most resistant species tested to Meloidogyne spp. (Rossner 1983; Kim et al. 1998).

\section{Diseases}

(a) Fungi-Canadian records: Erysiphe polygoni DC.: Alberta (Abbott and Currah 1989); Melanopsichium austroamericanum (Speg.) C. B. Beck-Canada: ON (1938, voucher in New York Botanical Gardens Herbarium). Utkhede et al. (2001) reported that $P$. aviculare from the Fraser Valley, British Columbia is not susceptible to powdery mildew (Erysiphe orontii Cast.).

U.S.A. records: Cercospora avicularis G. Wint.Delaware (Sumstine 1949); Eastern States, North Dakota, Texas (Anonymous 1960); Missouri (Anonymous 2004b), and South Dakota (Mankin 1969); Cercospora polygonacea Ell. \& Evrht.-Delaware (Sumstine 1949); Cercospora polygonorum Cke.-Delaware (Sumstine 1949); Erysiphe polygoni DC.-Florida (Alfieri et al. 1984), Georgia, North Dakota (Farr et al. 1989), Oklahoma (Preston 1945); South Dakota (Mankin 1969), Wyoming (Gilbertson et al. 1979); Melanopsichium austro-americanum (Speg.) C. B. BeckCalifornia (Anonymous 1960); Nigredo polygoni (Fuckel.) Arth.-North Dakota (Anonymous 2004b); Ovularia avicularis Peck —Nebraska (Braun 1995); Ovularia rigidula (Delacr.) Nannf.- Indiana, Nebraska, Wisconsin (Anonymous 1960); Peronospora polygoni Halst.-Iowa (Anonymous 1960); Phymatotrichum omnivorum (Shear) Duggar-Texas (Anonymous 1960); Puccinia aristidae Tracy-Colorado, Delaware, North Dakota, Nebraska, South Dakota (Anonymous 1960); Ramularia rufomaculans Peck-Iowa (Anonymous 1960); Septoria polygonorum Desm. - Minnesota and Wisconsin (Anonymous 1960), South Dakota (Mankin 1969); Uromyces polygoni (Pers.) Fuckel-Arkansas (Anonymous 1960), California (Anonymous 2004b), Florida (Alfieri et al. 1984), South Dakota (Mankin 1969); Uromyces polygoni-aviculare (Pers.) Karst.- Mississippi (Parris 1959); Ustilago utriculosa (Nees) Unger.-California (Anonymous 1960) and Iowa (Zundel 1953). Fungi, world-wide records: Additional fungi parasitizing Polygonum aviculare world-wide can be found in Brandenburger (1985) and Anonymous (2004b).

(b) Bacteria-no data.

(c) Viruses-Polygonum aviculare in North America was reported to be susceptible to: Arabis mosaic nepovirus (ArMV) (reviewed by Brunt et al. 2003), Carnation vein mottle potyvirus (CVMV) (reviewed by Brunt et al. 2003) and Tomato spotted wilt tospovirus (TSWV) (Zitter 2003). There is no North American publication regarding $P$. aviculare as a host for viruses. In Europe, the species is a host of: Beet necrotic yellow vein virus furovirus (BNYVV) (Kutluk et al. 2000) and Strawberry latent ringspot (?) nepovirus (SLRSV) (Caron and Hoof 1974).

\section{ACKNOWLEDGMENTS}

We would like to thank Paul Cavers, Stephen Darbyshire and two anonymous reviewers for their criticism and helpful comments on a previous version of this manuscript.

Abbott, S. P. and Currah, R. S. 1989. The larger cup fungi and other Ascomycetes of Alberta, an annotated checklist. Devonian Botanic Garden, University of Alberta, Edmonton, AB. 96 pp. Abrantes, I. M. O., Faria, C. A. T. and Santos, M. S. N. A. 1987. Root-lesion nematodes (Pratylenchus spp.) in Portugal. Nematologia Mediterranea 15: 375-378. 
Adkins, S. W. and Peters, N. C. B. 2001. Smoke derived from burnt vegetation stimulates germination of arable weeds. Seed Sci. Res. 11: 213-222.

Agrippa, H. C. (1486?-1535). 1651. Three books of occult philosophy. G. Moule, London UK.

Alex, J. F. 1964. Weeds of tomato and corn fields in two regions of Ontario. Weed Res. 4: 308-318.

Alex, J. F. 1992. Ontario weeds. Descriptions, illustrations and keys to their identification. Ontario Ministry of Agriculture and Food. Publication 505, Queen's Printer, Toronto, ON. 304 pp.

Alfieri, S. A., Jr., Langdon, K. R., Wehlburg, C. and Kimbrough, J. W. 1984. Index of plant diseases in Florida. Florida Dept. of Agric. \& Consumer Services, Div. of Plant Industry. Bull. No. 11 (Revised). 389 pp.

Al-Hazimi, H. M. A. and Haque, S. N. 2002. A new naphthoquinone from Polygonum aviculare. Nat. Prod. Lett. 16:115-118.

Alsaadawi, I. S. and Rice, E. L. 1982a. Allelopathic effects of Polygonum aviculare L. I. Vegetational patterning. J. Chem. Ecol. 8: $993-1009$.

Alsaadawi, I. S. and Rice, E. L. 1982b. Allelopathic effects of Polygonum aviculare L. II. Isolation, characterization, and biological activities of phytotoxins. J. Chem. Ecol. 8: 1011-1023.

Alsaadawi, I. S., Rice, E. L. and Karns, T. K. B. 1983. Allelopathic effects of Polygonum aviculare L. III. Isolation, characterization, and biological activities of phytotoxins other than phenols. J. Chem. Ecol. 9: 761-774.

Andrews, S. W., Krusberg, L. R. and Golden A. M. 1981. The host range, life-cycle and host-parasite relationships of Meloidoderita sp. Nematologica 27: 146-159.

Anonymous 1960. Index of plant diseases in the United States. USDA Agric. Handb. 165: 531.

Anonymous. 2002. Guide to weed control 2002. Publication 75. Ontario Ministry of Agriculture and Food, Toronto, ON. 331 pp.

Anonymous. 2004a. Invaders database system. Agricultural Research Service U.S.D.A. [Online] Available: http://invader.dbs. umt.edu [2004 Aug.].

Anonymous. 2004b. Systematic botany and mycology laboratory USDA. Host and fungal databases. [Online] Available: http://nt.arsgrin.gov/fungaldatabases/index.cfm [2004 Aug.].

Atkinson, H. J. and Sykes, G. B. 1981. An analysis from aerial photography of the spread of seed-borne Ditylenchus dipsaci in lucerne. Nematologica 27: 235-241.

Baranov, A. I. 1967. Wild vegetables in Manchuria. Econ. Bot. 21: $140-155$.

Bàrberi, P. and Lo Cascio, B. 2001. Long-term tillage and crop rotation effects on weed seedbank size and composition. Weed Res. 41: 325-340.

Bàrberi, P., Silvestri, N. and Bonari, E. 1997. Weed communities of winter wheat as influenced by input level and rotation. Weed Res. 37: 301-313.

Bàrberi, P., Cozzani, A., Macchia, M. and Bonari, E. 1998a. Size and composition of the seed bank under different management systems for continuous maize cropping. Weed Res. 38: 319-334.

Bàrberi, P., Macchia, M. and Bonari, E. 1998b. Comparison between seed extraction and seedling emergence methods for weed seed bank evaluation. Aspects Appl. Biol. 51: 9-14.

Bàrberi, P., Bonari, E. and Mazzoncini, M. 2001. Weed density and composition in winter wheat as influenced by tillage systems. First World Congress on conservation agriculture, Madrid, Spain. Volume 2, pp. 451-455.

Baskin, C. C. and Baskin, J. M. 1998. Seeds. Ecology, biogeography, and evolution of dormancy and germination. Academic Press, Toronto, ON. 666 pp.
Baskin, J. M. and Baskin, C. C. 1990. The role of light and alternating temperatures on germination of Polygonum aviculare seeds exhumed on various dates. Weed Res. 30: 397-402.

Batlla, D. and Benech-Arnold, R. L. 2003. A quantitative analysis of dormancy loss dynamics in Polygonum aviculare seeds: Development of a thermal time model based on changes in seed population thermal parameters. Seed Sci. Res. 13: 55-68.

Beaumont, F. (1584-1616) and Fletcher, J. (1579-1625). 1969. The works of Francis Beaumont and John Fletcher. Cambridge English Classics, Octagon Books, NY.

Begon, M., Harper, J. L. and Townsend, C. R. 1996. Ecology: individuals, populations, and communities. 3rd ed. Blackwell Science, Boston, MA. 1068 pp.

Bekker, R. M., Oomes, M. J. M. and Bakker, J. P. 1998. The impact of groundwater level on soil seed bank survival. Seed Sci. Res. 8: 399-404.

Bendixen, L. E, Reynolds, D. A., Riedel, R. M. 1979. An annotated bibliography of weeds as reservoirs for organisms affecting crops. I. Nematodes. Research Bulletin 1109. Ohio Agricultural Research and Development Centre U. S. 250 and Ohio 83 South Wooster, OH. 64 pp.

Binka, K. 2003. Palynological evidence for plant-animal interaction in the late Holocene. Veg. Hist. Archaeobot. 12: 37-47.

Bisset, N. G. and Wichtl, M. 2001. Herbal drugs and phytopharmaceuticals. A handbook for practice on a scientific basis with reference to German commission monographs. 2nd ed. CRC Press, Boca Raton, FL. 565 pp.

Brandenburger, W. 1985. Parasitische Pilze an Gefäspflanzen in Europa. Gustav Fischer Verlag, New York, NY. 1248 pp.

Braun, U. 1995. The powdery mildews (Erysiphales) of Europe. Gustav Fischer Verlag, New York, NY. 337 pp.

Brunt, A. A., Crabtree, K., Dallwitz, M. J., Gibbs, A. J., Watson, L. and Zurcher, E. J. (eds.) 2003. Plant viruses. [Online] Available: http://image.fs.uidaho.edu/vide/refs.htm [2004 Aug.].

Bubar, C., McColl, S. J. and Hall, L. M. 2000. Weeds of the prairies. Alberta Agriculture, Food and Rural Development, Edmonton, AB. 226 pp.

Bugg, R. L., Ehler, L. E. and Wilson, L. T. 1987. Effect of common knotweed (Polygonum aviculare) on abundance and efficiency of insect predators of crop pests. Hilgardia 55: 1-53.

Bulcke, R. and Callens, D. 1998. Herbicide resistance in weeds. What to learn from forty years of long-term herbicide experiments in apple and pear orchards? Comptes-rendus $6^{\text {ème }}$ symposium méditerraneen EWRS, Montpellier, France. 1998 May 13-15. pp: 173-180.

Bulcke, R., Willemijns, P., Stryckers, J. and Himme, M. van. 1987. Weed competition in maize. Mededelingen van de Faculteit Landbouwwetenschappen, Rijksuniversiteit Gent 52: 1185-1194.

Campagna, G. and Rapparini, G. 1997. Polygonum aviculare L. (code: POLAV) Informatore Agrario 53: 60.

Caron, J. E. A. and Hoof, H. A. 1974. The cultivation of virusfree Rosa rugosa. Bedrijfsontikkeling Jaargang 5: 1089-1091. Casquero, P.A., Rigueiro A., Lema, M. J. and Ron, A. M. de. 1993. Extraction of soil mineral salts by weeds in bean monoculture and intercropping of maize and bean. Proc. 1993 Congress of Spanish Weed Society, Lugo, Madrid, Spain, Spanish Weed Science Society. pp. 291-294.

Catullo, J. C., Sosa, C. A., Rodriguez, M. L. and Colombo, I. 1983. Weed incidence in wheat in relation to fertilization. Malezas 11: 179-203. [in Spanish, English abstract].

Chepil, W. S. 1946. Germination of weed seeds. I. Longevity, periodicity of germination, and vitality of seeds in cultivated soil. Sci. Agric. 26: 307-346. 
Chrtek, J. 1956. Promenlivost druhu Polygonum aviculare L. v CSR. Preslia 28: 362-368 [in Czech].

Chu, Y. I., Ho, K. Y. and Lee, Y. S. 1983. The effect of various host plants on the growth and development of the rice leaf roller (Cnaphalocrocis medinalis (Guenee)). Chinese J. Entomol. 3: 75-92.

Chung, I. M., Kim, K. J., Kim, K. H. and Ahn, J. K. 1994. Allelopathic effect of some weed species extracts and residues on alfalfa. Korean J. Crop Sci. 39: 285-294

Cialdella, A. M. 1992. Contribución al conocimiento de la inflorescencia en las especies argentinas del género Polygonum (Polygonaceae). Beitr. Biol. Pflanzen 67: 161-172 (in Spanish, with German and English abstracts).

Clark, G. H. and Fletcher, J. 1909. Farm weeds of Canada. 2nd ed. Dominion of Canada, Department of Agriculture, Branch of the Seed Commissioner. Ottawa, ON. 192 pp.

Conn, J. S. 1990. Seed viability and dormancy of 17 weed species after 4.7 years of burial in Alaska. Weed Sci. 38: 134-138.

Conn, J. S. and Farris, M. L. 1987. Seed viability and dormancy of 17 weed species after 21 months of burial in Alaska. Weed Sci. 35: 524-529.

Conn, J. S. and Deck, R. E. 1995. Seed viability and dormancy of 17 weed species after 9.7 years of burial in Alaska. Weed Sci. 43: 583-585.

Coquillat, M. 1951. Sur les plantes les plus communes à la surface du globe. Bull. Mens. Soc. Linn. Lyon. 20: 165-170.

Cornuti, I. 1635. (1966). Canadensium plantarum historia. The Sources of Science 37, Johnson Reprint Corporation, New York, NY. 238 pp.

Coruh, I. and Zengin, H. 2001. A study on the relation between seed reserve in soil and weed problem in wheat fields, Askale and Horasan district of Erzurum. Türkiye Herboloji Dergisi 4: 36-46. [in Turkish, English abstract].

Costea, M. and Tardif, F. J. 2003a. Nomenclatural changes in the genus Polygonum s.str. (Polygonaceae). Sida 20: 987-997.

Costea, M. and Tardif, F. J. 2003b. Polygonum aviculare subsp. rurivagum (Polygonaceae) in North America. Sida 20: 1709-1711. Costea, M., Tardif, F. J. and Hinds, H. 2005. Polygonum L. in Flora of North America Editorial Committee, eds. Flora of North America: North of Mexico. Vol. 5. New York and Oxford (accepted). Courtney, A. D. 1968. Seed dormancy and field emergence in Polygonum aviculare. J. Appl. Ecol. 5: 675-684.

Cousens, R. and Mortimer, M. 1995. Dynamics of weed populations. Cambridge University Press, Cambridge, New York, NY. $332 \mathrm{pp}$.

Cowan, M. M. 1999. Plant products as antimicrobial agents. Clin. Microbiol. Rev. 12: 564-582

Dale, M. R. T. and Thomas, A. G. 1987. The structure of weed communities in Saskatchewan fields. Weed Sci. 35: 348-355.

Dalmau, L., Plana, E. and Verdu, A. M. 1993. Solarizacion, trabajo del suelo y control de las malas hierbas en el Valles Oriental (Barcelona). Proc. of the 1993 Congress of the Spanish Weed Science Society, Lugo, Spain, 1-3 December 1993. pp: 264-267.

Darbyshire, S. J., Favreau, M. and Murray, M. 2000. Common and scientific names of weeds in Canada. Research Branch Agriculture and Agri-Food Canada, Ottawa, ON. Publ. 1379/B, $132 \mathrm{pp}$.

Dessaint, F., Chadoeuf, R. and Barralis, G. 1997. Nine years' soil seed bank and weed vegetation relationships in an arable field without weed control. J. Appl. Ecol. 34: 123-130.

Dorado, J., Del Monte, J. P. and López-Fando, C.1997. The effects of crop rotation and tillage system on weed flora in semiarid agrosystems. Proc. of the 1997 Congress of the Spanish Weed Science Society, Valencia, Spain. pp. 41-46.
Dorado, J., Del Monte, J. P. and López-Fando, C. 1999. Weed seedbank response to crop rotation and tillage in semiarid agroecosystems. Weed Sci. 47: 67-73.

Douglas, D. W. and Thomas, A. G. 1986. Weed survey of Saskatchewan mustard, lentil and dry pea crops. 1985. Weed Survey Series Publ. 86-2, Agriculture Canada, Regina, SK. 50 pp. Doyon, D., Bouchard, C. J. and Néron, R. 1986. Inventaire des mauvaises herbes dans les cultures du Québec. Vol. 1. Principales données des relevés floristiques et agronomiques de la région agricole de Québec (1980-1984) (02). Gouvernement du Québec, Ministère de l'Agriculture des Pêcheries et de l'Alimentation, QC. $41 \mathrm{pp}$.

Doyon, D., Bouchard, C. J. and Néron, R. 1987a. Inventaire des mauvaises herbes dans les cultures du Québec (1980-1984). Vol. 2. Principales données des relevés floristiques et agronomiques de la région agricole des Cantons-de-l'Est (05). Gouvernement du Québec, Ministère de l'agriculture des Pêcheries et de l'Alimentation, QC. 49 pp.

Doyon, D., Bouchard, C. J. and Néron, R. 1987b. Inventaire des mauvaises herbes dans les cultures du Québec (1980-1984). Vol. 3. Principales données des relevés floristiques et agronomiques de la région agricole de Richeliu (06). Gouvernement du Québec, Ministère de l'Agriculture des Pêcheries et de l'Alimentation, QC. 93 pp.

Doyon, D., Bouchard, C. J. and Néron, R. 1987c. Inventaire des mauvaises herbes dans les cultures du Québec (1980-1984). Vol. 4. Principales données des relevés floristiques et agronomiques de la région agricole de Richeliu (07). Gouvernement du Québec, Ministère de l'Agriculture des Pêcheries et de l'Alimentation, QC. 101pp.

Doyon, D., Bouchard, C. J. and Néron, R. 1987d. Inventaire des mauvaises herbes dans les cultures du Québec (1980-1984). Vol. 5. Principales données des relevés floristiques et agronomiques de la région agricole de Richelieu (10). Gouvernement du Québec, Ministère de l'Agriculture des Pêcheries et de l'Alimentation, QC. 93 pp.

Duke, J. A. 1985. CRC handbook of medicinal plants. CRC Press, Inc., Boca Raton, FL. 677 pp.

Edwards, D. I. and Taylor, D. P. 1963. Host range of an Illinois population of the stem nematode (Ditylenchus dipsaci) isolated from onion. Nematologica 9: 305-312.

Every, D. and Stufkens, M. A. W. 1999. Effect of the salivary proteinase from the New Zealand wheat bug, Nysius huttoni, on various exotic and endemic plant seeds. N. Z.. J. Crop Hortic. 27: 191-196.

Farr, D. F., Bills, G. F., Chamuris, G. P. and Rossman, A. Y. 1989. Fungi on plants and plant products in the United States. APS Press. The American Phythopatological Society, St. Paul, MN. $1152 \mathrm{pp}$.

Farrell, J. A. and Stufkens, M. W. 1993. Phenology, diapause, and overwintering of the wheat bug, Nysius huttoni (Hemiptera: Lygaeidae), in Canterbury, New Zealand. N. Z. J. Crop Hortic. 21: 123-131.

Fernandez-Quintanilla, C., Navarrete, L., Sanchez-Giron, V. and Hernanz, J. L. 1984. The influence of direct drilling on the weed flora of cereal crops in central Spain. Comptes rendus du 7ème colloque international sur l'écologie, la biologie et la systématique des mauvaises herbes, 1984, 1: 431-436.

Firbank, L. and Smart, S. 2002. The changing status of arable plants that are important food items for farmland birds. Aspects Appl. Biol. 67: 165-170.

Foderaro, M. A. and Ungar, I. A. 1997. Growth and survival of Polygonum aviculare at a brine-contaminated site in southwestern Ohio. Am. Midl. Nat. 138: 140-152. 
Forcella, F., Wilson, R. G., Dekker, J. Kremer, R. J., Cardina, J., Anderson, R. L. Alm, D., Renner, K. A., Harvey, R. G., Clay, S. and Buhler, D. D. 1997. Weed seedbank emergence across the Corn Belt. Weed Sci. 45: 67-76.

Frick, B., Thomas, A. G. and Wise, R. F. 1990. Weeds of corn, soybean, and winter wheat fields under conventional, conservation and no-till management systems in southwestern Ontario 1988 and 1989. Weed Survey Series Publication 90-1, Agriculture Canada, Regina, SK. 239 pp.

Froud-Williams, R. J., Chancellor, R. J. and Drennan, D. S. H. 1984. The effects of seed burial and soil disturbance on emergence and survival of arable weeds in relation to minimal conditions. $\mathbf{J}$. Appl. Ecol. 21: 629-641.

Fuchs, L. (1542). 1999. The great herbal of Leonhart Fuchs. De historia stirpium commentarii insignes. G. Meyer, E. E. Trueblood, and J. L. Heller, eds. Vol. 2. Stanford University Press, Stanford, CA. 896 pp.

Garcia, D. L. Q., Chávez, R. P. and Sánchez, M. 1998. Morfologia de los granos de polen de la familia Polygonaceae del Valle de Mexico, Mexico. Phytologia 85: 1-18. [in Spanish, with English abstract].

Gaskin, T. A. 1958. Weed hosts of Meloidogyne incognita in Indiana. Plant Dis. Rep. 42: 802-803.

Gasquez, J., Compoint, J. P., Barralis, G., Chadoeuf, R. and Lonchamp, J. P. 1978. Essai de taxonomie d'une espèce adventice annuelle: Polygonum aviculare L. Ann. Amèlior. Plant. 28: 565-577. Geber, M. A. 1989. Interplay of morphology and development on size inequality: A Polygonum greenhouse study. Ecol. Monogr. 59: 267-288.

Geber, M. A. 1990. The cost of meristem limitation in Polygonum arenastrum: Negative genetic correlation between fecundity and growth. Evolution 44: 799-819.

Geber, M. A. and Dawson, T. E. 1990. Genetic variation in and covariation between leaf gas exchange, morphology, and development in Polygonum arenastrum, an annual plant. Oecologia 85: $153-158$.

Geber, M. A. and Dawson, T. E. 1997. Genetic variation in stomatal and biochemical limitations to photosynthesis in the annual plant, Polygonum arenastrum. Oecologia 109: 535-546.

Gerard, J. (1597). 1975. The herbal or general history of plants. Dover Publications, New York, NY. 1630 pp.

Gilbertson, R. L., Cummins, G. B. and Darnall, E. D. 1979. Indexes to W.G. Solheim's Mycoflora Saximontanensis Exsiccata. Mycotaxon 10: 49-92.

Gomez de Aizpurua, C. 1994. Note on the morphology of four caterpillars (Insecta: Lepidoptera) not described previously. Boletin de Sanidad Vegetal, Plagas 20: 955-962. [in Spanish, English abstract].

Gonzalez Begne, M., Yslas, N., Reyes, E., Quiroz, V., Santana J. and Jimenez, G. 2001. Clinical effect of a Mexican Sanguinaria extract (Polygonum aviculare L.) on gingivitis. J. Ethnofarmacology 74: 45-51.

Grela, E. R., Czech, A. and Krukowski, H. 2003. Influence of dietary supplementation of herbs on performance and blood parameters in piglets. Medycyna Weterynaryjna 59: 410-412.

Grime, J. P., Hodgson, J. G. and Hunt, R. 1988. Comparative plant ecology. A functional approach to common British species, Unwin Hyman, London, UK. 742 pp.

Groh, H. and Frankton, C. 1949. The 1948-1949 Canadian weed survey. Can. Dept. Agr. Reports 5th-7th, Ottawa, ON, 144 pp. Gronovius, J. F. 1762. Flora Virginica: Exhibens Plantas, Quas Johannes Claytonus in Virginia Crescentes Observavit, Collegit \& Obtulit Joh. Fred. Gronovio, Cujus Studio \& Opera Descriptae \& in Ordinem Sexualem Systematicum Redactae Sistuntur, Lugduni Batavorum. $176 \mathrm{pp}$.
Grundy, A. C., Mead, A. and Bond, W. 1996. Modeling the effect of weed-seed distribution in the soil profile on seedling emergence. Weed Res. 36: 375-384.

Gunther, R. T. 1959. The Greek herbal of Dioscorides. Hafner Publishing Co., New York, NY. 701 pp.

Haar, M. J., Fennimore, S. A., Ajwa, H. A. and Winterbottom, C. Q. 2003. Chloropicrin effect on weed seed viability. Crop Prot. 22: 109-115.

Hallgren, E. 1996. Do the weed flora and effect of a herbicide change with time? Proc. second international weed control congress, Copenhagen, Denmark, 1996 Jun. 25-28: Volumes 1-4, 1996. pp. 1355-1368.

Hamill, A. S., Wise, R. F. and Thomas, A. G. 1983. Weed survey of Essex and Kent Counties-1978 and 1979. Weed Survey Series Publ. 83-01 Canada Dept. of Agriculture, Regina, SK. 134 pp.

Hammerton, J. L. 1964. Variations in the after-ripening requirements of Polygonum aviculare L. seeds. Proc. Br. Weed Control Conf. 7: 628-634.

Hanf, M. 1983. The arable weeds of Europe with their seedlings and seeds. BASF United Kingdom Limited, Suffolk, UK. 494 pp. Haraldson, K. 1978. Anatomy and taxonomy in Polygonaceae subfam. Polygonoideae Meisn. emend Jaretzky. Symb. Bot. Upsal. 22: 1-95.

Harley, J. L. and Harley, E. L. 1987. A check-list of mycorrhiza in the British Flora. New Phytol. 105: 1-102.

Harper, J. L. 1977. Population biology of plants. Academic Press, New York, NY. 892 pp.

Hartl, W. 1989. Influence of undersown clovers on weeds and on the yield of winter wheat in organic farming. Agric. Ecosyst. Environ. 27: 389-396.

Hedberg, O. 1946. Pollen morphology in the genus Polygonum L. s. lat. and its taxonomical significance. Svensk Bot. Tid. 40: 371-404.

Heikertinger, F. 1951. Bestimmungstabellen der paläarktischen Arten der Gattung Podagrica Foudr., Mantura Steph. und Chaetocnema Steph. Kol. Rundsch. 32: 1-84.

Hill, K. A., Townsend, R. P. C., Hill, M. J. and Hampton, J. C. 1999. Weed seeds in white clover seed lots: loses during seed cleaning. Agronomy New Zealand 29: 27-30.

Hoen, P. 1999. Glossary of pollen and spore terminology. Laboratory of Palaeobotany and Palynology, Utrecht. [Online] Available: http://www.bio.uu.nl/ palaeo/glossary/glos-int.htm [2003 Aug.].

Holm, L., Doll, J., Holm, E., Pancho, J. and Herberger, J. 1997. World weeds: Natural histories and distribution. John Wiley \& Sons Inc., Toronto, ON. 1129 pp.

Holmes, R. J. and Froud-Williams, R. J. 2001. The predation and dispersal of weed seeds by birds. The BCPC ConferenceWeeds 2001. pp. 333-336.

Hostounsky, Z. 1984. Production of microsporidia pathogenic to the Colorado potato beetle (Leptinotarsa decemlineata) in alternate hosts. J. Invertebr. Pathol. 44: 166-171.

Hu, M., Li, S. Q., Chen, Z. P. and Yan, D. P. 1989. Observations on Entomoscelis orientalis Motschulsky and its control effects on Polygonum aviculare. Insect Knowledge 26: 280-282.

Ivany, J. A. 1980. The 1978 weed survey of grain fields in Prince Edward Island. Weed Survey Series, Publ. 80-2, Agriculture Canada, Charlottetown, PE. 59 pp.

Ivany, J. A. and Thomas, A. G. 1983. The 1979 weed survey of grain fields in Prince Edward Island. Weed Survey Series, Publ. 83-3, Agriculture Canada, Charlottetown, PE. 60 pp.

Johri, B. M., Ambegaokar, K. B. and Srivastava, P. S. 1992. Comparative embryology of Angiosperms. Vol. 1. SpringerVerlag, Berlin, Germany. 614 pp. 
Jones, R., Alemeged, Y., Medd, R. and Vere, D. 2000. The distribution, density and economic impact of weeds in Australian annual winter cropping systems. CRC for Weed Management Systems Technical Series No. 4, University of Adelaide, Australia. $58 \mathrm{pp}$.

Justice, O. L. 1941. A study of dormancy in seeds of Polygonum. Mem. Cornell Univ. Agric. Exp. Stn. 235: 1-43.

Karlsson, T. 2000. The genus Polygonum L. Pages 255-273 in B. Jonsell ed. Flora Nordica. Vol. 1. Stockholm, Sweden.

Kasowska, D. 2002. Mycorrhizal status of plants in two successional stages on spoil heaps from fireloam mining in Lower Silesia (SW Poland). Acta Soc. Bot. Pol. 71: 155-161.

Khan, M. A. and Ungar, I. A. 1998. Seed germination and dormancy of Polygonum aviculare L. as influenced by salinity, temperature and gibberellic acid. Seed Sci. Technol. 26: 107-117.

Kiger, W. and Porter, D. M. 2001. Categorical glossary for the flora of North America project. Hunt Botanical Institute. [Online] Available: http://huntbot.andrew.cmu.edu/HIBD/Departments/ DB-INTRO/IntroFNA.shtml [2004 Aug.].

Kim H. H., Choo H. Y., Park C. G., Lee J. J. and Jeong D. Y. 1998. Antagonistic plant survey for the biological control of rootknot nematodes in greenhouses. Korean J. App. Entomol. 37: 91-95

Kim, H. J., Woo, E. R. and Park, H. 1994. A novel lignan and flavonoids from Polygonum aviculare. J. Nat. Prod. 57: 581-586.

Kim, K. U., Park Y. G. and Kwack, S. H. 1995. Development of useful secondary product through plant cell culture. Korean J. Weed Sci. 15: 154-159.

Kismali, S. and Madanlar, N. 1990. The role of Chrysomelidae (Coleoptera) species for the biological control of weeds and the status of the species in Izmir. Proc. 2nd Turkish National Congress of Biological Control 1990. pp. 299-308.

Knight, P. R. 1979. Suspected nitrite toxicity in horses associated with the ingestion of wireweed (Polygonum aviculare). Aust. Vet. Pract. 9: 175-177.

Knott, C. M. 1990. Weed control in other arable and field vegetable crops. Chapter 12. Pages 329-366 in R. J. Hance and K. Holly, eds. Weed control handbook: Principles. 8th ed. Blackwell, Oxford, UK.

Kress, O. 1988. The wild flora of intensively managed vegetable areas and neighboring strips. Zeitschrift für Pflanzen krankheiten und Pflanzenschutz Sonderheft 11: 189-196.

Kruk, B. C. and Benech-Arnold, R. L. 1998. Functional and quantitative analysis of seed thermal responses in prostrate knotweed (Polygonum aviculare) and common purslane (Portulaca oleracea). Weed Sci. 46: 83-90.

Kutluk, N. D., Erkan, S. and Bicken, S. 2000. Weeds as hosts for Rhizomania's agent. Z. Pflanzenk. Pflanzen. 17: 167-171.

Kutschera, L. 1960. Wurzelatlas mitteleuropäischer Ackerunkräuter und Kulturpflanzen. DLG-Verlags-GMBH, Frankfurt am Main, Germany. 574 pp.

Kutschera, L. and Sobotik, M. 1992. Wurzelatlas mitteleuropäischer Gründlandpflanzen. Band 2. Pterydophyta und Dicotyledoneae (Magnoliopsida). Gustav Fischer, Stuttgart, Germany. 261 pp.

Kutyna, I. 1998. Plant communities forming on detritus-calcareous gyttja deposits on arable land. Folia Universitatis Agriculturae Stetinensis, Agricultura 69: 55-64. [in Polish, English abstract].

Lamp, C. and Collet, F. 1989. Field guide to weeds in Australia. 3rd ed. Inkata Press, Melbourne, Australia. 351 pp.

Laubengayer, R. A. 1937. Studies in the anatomy and morphology of the Polygonaceous flower. Am. J. Bot. 24: 329-343.

Leeson. J. Y., Thomas, A. G. and Hall, L. M. 2001. Alberta weed survey. Cereal, oilseed and pulse crops. Weed Survey Series Publ. 02-1 Agriculture Canada, Saskatoon, SK. 213 pp.
Leeson, J. Y., Thomas, A. G., Andrews, T., Brown, K. R. and Van Acker, R. C. 2002. Manitoba weed survey of cereal and oilseed crops in 2002. Weed Survey Series Publ. 02-2, Agriculture Canada, Saskatoon, SK. 151 pp.

Leeuwen, P., Punt, W. and Hoen P. P. 1988. Polygonaceae. Rev. Paleobot. Palynol. 57: 81-151.

Lefevre, P. 1956. Influence du milieu et des conditions d'exploration sur le développement des plantes adventices. Effet particulier du pH et l'état calcique. Ann. Agron. Paris 7: 299-347.

Lindman, C. A. M. 1912. Wie ist die kollektivart Polygonum aviculare zu spalten. Svensk Bot. Tid. 6: 673-696 [in German].

Lipecki, J. and J. Szwedo. 1988. Studies on the weed occurrence in herbicide strips in orchards in eastern Poland. VIIIe Colloque International sur la Biologie, l'Ecologie et la Systematique des Mauvaises Herbes. 1: 305-312.

Lonay, H. 1922. Genèse et anatomie des péricarpes ex des spermodermes chez les Polygonacées. (Polygonum aviculare L.). Mem. Soc. R. Sci. Liège 3: 1-88.

López, D. J. and Romero, M. D. 1988. Heterodera schachtii (Nematoda: Heteroderidae) in nitrophoric communities of Salamanca (Spain). Nematologia Mediterranea 16: 59-61,

López, J. A. and Mattiacci, M. R. 1983. Damage caused by prostrate knotweed (Polygonum aviculare L.) during the establishment of a sown pasture. Malezas 11: 246-251 [in Spanish, English abstract].

Löve, A. and Löve, D. 1956. Chromosomes and taxonomy of eastern North American Polygonum. Can. J. Bot. 34: 501-521.

Lovett, J. 1986. Allelopathy: The Australian experience. Pages 75-110 in A. R. Putnam and C. S. Tang, eds. The science of allelopathy. John Wiley \& Sons, New York, NY.

Lutman, P. J. W., Cussans, G. W., Wright, K. J., Wilson, B. J., Wright, G. M. and Lawson, H. M. 2002. The persistence of seeds of 16 weed species over six years in two arable fields. Weed Res. 42: 231-241.

Mankin, C. J. 1969. Fungous diseases on non-grass plants in South Dakota. Agric. Exp. Sta. South Dakota State Univ. Tech. Bull. 36: 1-28.

Maoz, M. and Neeman, I. 1998. Antimicrobial effects of aqueous plant extracts on the fungi Microsporum canis and Trichophyton rubrum and on three bacterial species. Lett. Appl. Microbiol. 26: 61-63

Markham, G. (1568?-1637) (first published in 1615). 1994. The English housewife. McGill-Queens University Press. 321 pp.

Marocchi, G. 1994. Un insetto utile come 'diserbante'. Vita in Campagna 12: 50.

Marshall, E. J. P., Brown, V. K., Boatman, N. D. Lutman, P. J. W., Squire, G. R. and Ward, L K. 2003. The role of weeds in supporting biological diversity within crop fields. Weed Res. 43: 77-89.

Massicotte, H. B., Melville, L. H., Peterson, R. L. and Luoma, D. L. 1998. Anatomical aspects of field ectomycorrhizas on Polygonum viviparum (Polygonaceae) and Kobresia bellardi (Cyperaceae). Mycorrhiza 7: 287-292.

McPhee, C., Bonser, S. and Aarssen, L. W. 1997. The role of apical dominance in the interpretation of adaptive architecture in prostrate plant species. Ecoscience 4: 490-500.

McGuffin, N. J. 1986. Dye plants of Ontario. Concord, ON. 299 pp.

Meerts, P. 1992. An experimental investigation of the life history and plasticity in two cytotypes of Polygonum aviculare L. subsp. aviculare that coexist in an abandoned arable field. Oecologia 92: 442-449.

Meerts, P. 1995. Phenotypic plasticity in the annual weed Polygonum aviculare. Bot. Acta 108: 414-424. 
Meerts, P. 2002. CAB International. Crop Protection Compendium. Wallingford, UK. [Online] Available: http://www.cabicompendium. org [2003 Aug.].

Meerts, P. and Vekemans, X. 1991. Phenotypic plasticity as related to trampling within a natural population of Polygonum aviculare subsp. aequale. Acta Oecol. 12: 203-212.

Meerts, P. and Garnier, E. 1996. Variation in relative growth rate and its components in the annual Polygonum aviculare in relation to habitat disturbance and seed size. Oecologia 108: 438-445.

Meerts, P., Briane, J.-P. and Lefèbre, C. 1990. A numerical taxonomic study of Polygonum aviculare complex (Polygonaceae) in Belgium. Plant Syst. Evol. 173: 71-89.

Meerts, P., Baya, T. and Lefèbre, C. 1998. Allozyme variation in the annual weed species complex Polygonum aviculare (Polygonaceae) in relation to ploidy level and colonizing ability. Plant Syst. Evol. 211: 239-256.

Mertens, T. R. and Raven, P. H. 1965. Taxonomy of Polygonum section Polygonum (Avicularia) in North America. Madroño. 18: 85-92.

Metcalfe, C. R. and Chalk, L. 1950. Anatomy of the Dicotyledons. Ed. 1. Clarendon Press, Oxford, UK. 1500 pp.

Miele, S., Macchia, M. and Benvenuti, S. 2000. Soil seed bank evaluation for weed control strategy in tobacco: first results of a European Community funded project. Abstracts of the 3rd International Weed Science Congress. Foz do Iguassu, Brazil. p. 16 [Abstr.].

Milton, S. J., Dean, W. R. J. and Klotz, S. 1997. Effects of smallscale animal disturbances on plant assemblages of set-aside land in Central Germany. J. Veg. Sci. 8: 45-54.

Missouri Botanical Garden. 2004. $W^{3}$ Tropicos database (online). Chromosome counts and references. [Online] Available: http://mobot.mobot.org/W3T/Search/vast.html [2003 Aug.].

Montenegro-Gálvez, V. and Criollo-Escobar, H. 1978. The effect of competition between cool climate Phaseolus beans cv. Diacol Andino and weeds. Revista de Ciencias Agricolas 8: 26-34 [in Spanish, English abstract].

Nadasy, M. A. 1983. Food preference studies on adults of some Sitona species. Novenyvedelem 19: 298-304.

Nan, J. X., Park, E. J., Kim, H. J., Ko, G. and Sohn, D. H. 2000. Antifibrotic effects of the methanol extract of Polygonum aviculare in fibrotic rats induced bile duct ligation and scission. Biol. Pharm. Bull. 23: 240-243.

Nikitina, K. K. 1965. O semennom razmnozhenii sporysha. Ulyanovskij ped. in-t. Uchenye Zapiski. 20: 31-37. [in Russian].

O'Connell, M. and Molloy, K. 2001. Farming and woodland dynamics in Ireland during the Neolithic. Proc. R. Ir. Acad. 101B: 99-128.

Ohta, I., Matsuda, K. and Matsumoto, Y. 1998. Feeding stimulation of strawberry leaf beetle, Galerucella vittaticollis Baly (Coleoptera: Chrysomelidae) by quercetin glycosides in polygonaceous plants. Jpn. J. Appl. Entomol. Z. 42: 45-49.

Oorschot, J. L. P. van and Straathof, H. J. M. 1988. On the occurrence and distribution of chlorplastic resistance of weeds to triazines in the Netherlands. VIIIe Colloque International sur la Biologie, l'Ecologie et la Systematique des Mauvaises Herbes. 1: 267-275.

Ozer, Z. and Hasimoglu, S. 1977. Preservation of germination ability of weed seeds passed through the gastro-intestinal tract of sheep. J. Turkish Phytopathol. 6: 105-110.

Paolini, R., Del Puglia, S., Principi, M., Barcellona, O. and Riccardi, E. 1998. Competition between safflower and weeds as influenced by crop genotype and sowing time. Weed Res. 38: 247-255.

Parris, G. K. 1959. A revised host index of Mississippi plant diseases. Mississippi State Univ., Bot. Dept. Misc. Publ. 1: 11-46.
Plachcinska, J., Matacz, D., Krzysztofik, R., Dabrowa, A., Brzosko, W. J. and Ozarowski, A. 1984. Influence of medicinal herbs on the immune system. I. Induction of endogenous interferon. Fitoterapia 55: 346-348.

Pliny the Elder (ca. 23-79 AD). 1951. Natural history. Vols. V and VI translated by W. H. S. Jones and D. Litt. The Loeb Classical Library, Cambridge, Massachusetts and Harvard University Press, London, UK.

Pollard, F. and Cussans, G. W. 1981. The influence of tillage on the weed flora in a succession of winter cereal crops on a sandy loam soil. Weed Res. 21: 185-190.

Popov, A. I. 1994. Mineral substances in the grass knotweed. Vaprosy Pitanya 1/2: 38-39.

Preston, D. A. 1945. Host index of Oklahoma plant diseases. Oklahoma Agric. Coll. Agric. Exp. Sta. Techn. Bull. T-21: 1-168. Qasem, J. R. 1995. Critical period of weed interference in irrigated snap bean (Phaseolus vulgaris). Adv. Hortic. Sci. 9: 23-26.

Rafii, S. 1993. Interaction between various methods of weed control and increased fertilizer with different wheat cultivars in the Islamic Republic of Iran. Wechselwirkung zwischen unterschiedlichen Methoden der Unkrautbekampfung und einer erhohten Dungung bei verschiedenen Weizensorten in der Isl. Rep. Iran. 176 pp. [in German, English abstract].

Ransom, E. R. 1935. Inter-relations of catalase, respiration, afterripening and germination in some dormant seeds of the Polygonaceae. Am. J. Bot. 22: 815-825.

Rasmussen, J. 1992. Experimental approaches to mechanical weed control in field peas. IXe Colloque international sur la biologie des mauvaises herbes, 16-18 September 1992, Dijon, France. pp. 129-138.

Raso, E., Venturi, T. and Vazzana, C. 2001. Mechanical weed control in soft wheat. Informatore Agrario 57: 41-44.

Re, L. D., Galassi, T. and Pizzi, M. 1996. Techniques of seed bed preparation for weed control in beet. Informatore Agrario 52: 31-33.

Read, B. E. 1946. Famine foods listed in the Chiu huang pen ts'ao [of Ting Wang Chou] giving their identity, nutritional values and notes on their preparation. Henry Lester Institute of Medical Research, Shanghai, China. 93 pp.

Reeves, F. B., Wagner, D., Moorman, T. and Kiel, J. 1979. The role of endomycorrhizae in revegetation practices in the semi-arid west. I. A comparison of incidence of mycorrhizae in severely disturbed vs. natural environments. Am. J. Bot. 66: 6-13.

Richards, M. C. 1991. Evaluation of the Baertschi brush-hoe and Tearaway spring-tined weeder for weed control in spring barley. Ann. Appl. Biol. 118: 140-141.

Rifai, M. N., Lacko-Bartosová, M. and Brunclík, P. 2001. Performance of two thermal weeders in apple orchards. Acta Fytotechnica et Zootechnica 4: 81-82.

Roberts, H. A. 1981. Seed banks in soils. Adv. Appl. Biol. 6: 1-5. Roberts, H. A. and Feast, P. M. 1970. Seasonal distribution of emergence in some annual weeds. Exp. Hortic. 21: 36-41.

Roberts, H. A. and Chancellor, R. J. 1986. Seed banks of some arable soils in English midlands. Weed Res. 4: 251-257.

Ronse Decraene, L. P. and Akeroyd, J. R. 1988. Generic limits in Polygonum and related genera (Polygonaceae) on the basis of floral characters. Bot. J. Linn. Soc. 98: 321-371.

Ronse Decraene, L. P. and Smets, E. F. 1991. The floral nectaries of Polygonum S.L. and related genera (Persicarieae and Polygoneae): position, morphological nature and semophylesis. Flora 185: 165-185.

Ronse Decraene, L. P., Hong, S.-P. and Smets, E. F. 2000. Systematic significance of fruit morphology and anatomy in tribes Persicarieae and Polygoneae (Polygonaceae). Bot. J. Linn. Soc. 134: 301-337. 
Rossner, J. 1983. Attack of weeds by nematodes of the genus Pratylenchus. Z. Pflanzenk. Pflanzen. 90: 22-27 [in German, English abstract].

Rousseau, C. 1968. Histoire, habitat et distribution de 220 plantes introduites au Québec. Naturaliste Can. 95: 49-169.

Royer, F. and Dickinson, R. 1999. Weeds of Canada and the Northern United States. Lone Pine Publishing and University of Alberta Press, Edmonton, AB. 434 pp.

Rutkowska, B. and Stypinski, P. T. 1997. The use of grass species and cultivars in environmental protection in Poland. International Conference Nitra, Slovakia, 23 October 1997. pp. 203-207.

Sahadeva, S. 2001. Interception of weeds in imported wheat grain consignments. Ann. Agric. Res. 22: 83-87.

Salisbury, E. 1961. Weeds and aliens. Collins Clear-Type Press, London and Glasgow, UK. 384 pp.

Sas-Piotrowska, B. and Piotrowski, W. 1997a. The growth and development of potato pathogens on the media with extracts from Polygonaceae plants. 2. Pathogens causing tuber diseases. Biuletyn Instytutu Ziemniaka 48: 91-99.

Sas-Piotrowska, B. and Piotrowski, W. 1997b. Evaluation of fungicidal action of plant extracts on damping-off fungi in sugarbeet. Biuletyn Instytutu Hodowli i Aklimatyzacji Roslin 202: 253-258.

Schmid, K. 1983. Untersuchungen an Polygonum aviculare s.l. in Bayern. Mitt. Bot. München 19: 29-149.

Scholz, H. 1958. Die systematic der Europaischen Polygonum aviculare L. Ber. Deutsch Bot. Ges. 71: 427-437.

Scibisz, K., Sadowski, A., Polensy, F., Muller, W. and Olszak, R. W. 1995. Ecological methods of soil management in scab resistant apple orchard. Acta Hortic. 422: 429-430.

Scott, J. K. and Yeoh, P. B. 1998. Host range of Brachycaudus rumexicolens (Patch), an aphid associated with Polygonaceae. Biol. Control 13: 135-142.

Shakespeare, W. (1564-1616). 1924. A midsummer-night's dream. Cambridge, University Press, Cambridge, UK.

Small, J. K. 1895. A monograph of the North American species of the genus Polygonum. Mem. Dept. Bot. Columbia Coll. 1: 1-183. Smolarz, H. D. 2002. Flavonoid glycosides in nine Polygonum L. taxa. Acta Soc. Bot. Pol. 71: 29-33.

Sokolova, N. P. and Bogdanova, T. L. 1966. Structure of roots and stems of knotweed. Botanika 126: 157-163. [in Russian].

Sotherton, N. W. 1982. Predation of a chrysomelid beetle (Gastrophysa polygoni) in cereals by polyphagous predators. Ann. Appl. Biol. 101: 196-199.

Sotherton, N. W. 1990. The environmental benefits of conservation headlands in cereal fields. Pesticide Outlook. 1: 14-18.

Stajner, D., Mimica-Dukic, N. and Braic, M. 1997. Oxygen radical scavenging activity of Reatival(R). Fitoterapia 68: 261-264.

St.-Arnaud, M. and Viceent, G. 1988. Influence of high salt levels on the germination and growth of five potentially utilizable plants for median turfing in northern climates. J. Environ. Hortic. 6: $118-121$.

Stevens, O. A. 1932. The number and weight of seeds produced by the weeds. Am. J. Bot. 19: 784-794.

Stuckey, R. L. and Barkley, T. M. 1993. Weeds in North America in Flora of North America Editorial Commitee. Flora of North America: North of Mexico. Vol. 1. [Online] Available: http://www.fna.org/FNA/Volume/V01/Chapter08.shtml [2003 Aug.].

Styles, B. T. 1962. The taxonomy of Polygonum aviculare and its allies in Britain. Watsonia 5: 177-214.

Sumstine, D. R. 1949. The Albert Commons collection of fungi in the herbarium of the Academy of Natural Sciences in Philadelphia. Mycologia 41: 11-23
Thomas, A. G. 1977. Weed survey of cultivated land in Saskatchewan. Agriculture Canada Research Station, Regina, SK. 103 pp.

Thomas, A. G. 1978a. Weed survey of cultivated land in Saskatchewan. Agriculture Canada Research Station, Regina, SK. $113 \mathrm{pp}$.

Thomas, A. G. 1978b. Weed survey of cultivated land in Manitoba. Agriculture Canada Research Station, Regina, SK. 103 pp.

Thomas, A. G. 1979. Weed survey of cultivated land in Saskatchewan. Agriculture Canada Research Station, Regina, SK. $141 \mathrm{pp}$.

Thomas, A. G. and Wise, R. F. 1983a. Peace River region of British Columbia weed survey of cereal and oil seed crops-1978, 1979 and 1980. Weed Survey Series Publ. 83-4, Agriculture Canada, Regina, SK. 171 pp.

Thomas, A. G. and Wise, R. F. 1983b. Weed survey of Saskatchewan cereal and oilseed crops from 1976 to 1979. Weed Survey Series Publ. 83-6, Agriculture Canada, Regina, SK. 260 pp. Thomas, A. G. and Wise, R. F. 1985. Dew's Alberta weed survey (1973-1977). Weed Survey Series Publ. 85-3, Agriculture Canada, Regina, SK. 134 pp.

Thomas, A. G. and Wise, R. F. 1986a. Weed survey of Saskatchewan sunflower fields 1985. Weed Survey Series Publ. 86-1, Agriculture Canada, Regina, SK. 50 pp.

Thomas, A. G. and Wise, R. F. 1986b. Weed survey of Saskatchewan winter wheat fields 1985 . Weed Survey Series Publ. 86-3, Agriculture Canada, Regina, SK. 85 pp.

Thomas, A. G. and Wise, R. F. 1987. Weed survey of Saskatchewan cereal and oilseed crops 1986. Weed Survey Series Publ. 87-1, Agriculture Canada, Regina, SK. 251 pp.

Thomas, A. G. and Wise, R. F. 1988. Weed survey of Manitoba cereal and oilseed crops 1986. Weed Survey Series Publ. 88-1, Agriculture Canada, Regina, SK. 251 pp.

Thomas, A. G. and Wise, R. F. 1989. Weed survey of Saskatchewan winter wheat fields Weed Survey Series Publ. 89-1, Agriculture Canada, Regina, SK. 248 pp.

Thomas, A. G., Wise, R. F. and Clayton, G. 1986. Port Vermillon area of Alberta weed survey in cereal and oilseed fields. Weed Survey Series Publ. 86-4, Agriculture Canada, Regina, SK. $98 \mathrm{pp}$.

Thomas, A. G., Doohan, D. J. and McCully, K. V. 1994. Weed survey of spring cereals in New Brunswick. Phytoprotection 75: $113-124$

Thomas, A. G., Frick, B. and Hall, L. M. 1998. Alberta weed survey. Weed Survey Series Publ. 98-2. Agriculture Canada, Saskatoon, SK. 241 pp.

Thomas, A. G., Wise, R. F., Frick, B. and Juras, L. T. 1996. Saskatchewan weed survey. Weed Survey Series Publ. 96-1. Agriculture Canada, Saskatoon, SK. 419 pp.

Thomas, A. G., Frick, B., Van Acker, R. C., Knezevic, S. Z. and Joosse, D. 1998. Manitoba weed survey. Weed Survey Series Publ. 98-1. Agriculture Canada, Saskatoon, SK. 192 pp.

Thompson, K., Bakker, J. and Bekker, R. 1996. The soil seed banks of north west Europe. Methodology, density and longevity. Cambridge University Press, Cambridge UK. 288 pp.

Titus, J. H. and Tsuyuzaki, S. 2002. Arbuscular mycorrhizal distribution in relation to microsites on recent volcanic substrates of Mt. Koma, Hokkaido, Japan. Mycorrhiza 12: 271-275.

Tosso, T. J., Ferreyra, E. R. and Munoz, S. L. 1986. Weed seeds transported by irrigation water. I. Quantitative evaluation and factors involved. Agricultura Tecnica 46: 119-123.

Tottman, D. R. and Wilson, B. J. 1990. Weed control in small grain cereals. Pages 301-328 in R. J. Hance and K. Holly, eds. 
Weed control handbook: Principles. Blackwell, Oxford, UK. Townshend, J. L. and Davidson, T. R. 1962. Some weed hosts of the northern root knot nematode, Meloidogyne hapla in Ontario. Can. J. Bot. 40: 543-548.

Trefas, H., Christal, A., McKinlay, R. G., Armstrong, G. and Bujaki, G. 2001. Experiments for assessing weed seed consumption of Pterostichus melanarius (Illiger) (Coleoptera: Carabidae). Novenyvedelem 37: 115-122 [in Hungarian, English abstract]. Tsuruuchi, T. 1986. Studies on weeds in upland wheat and barley fields in Nagasaki Prefecture. VI. Influence of summer flooding on the survival of some winter weed seeds in soil. Report of the Kyushu Branch of the Crop Science Society of Japan. 87: 45-47. Tunon, H., Olavsdotter, C. and Bohlin, L. 1995. Evaluation of anti-inflammatory activity of some Swedish medicinal plants. Inhibition of prostaglandin biosynthesis and PAF-induced exocytosis. J. Ethnopharmacol. 48: 61-76.

Turgeon, A. J., Kral, D. M. and Viney, M. K. (eds.). 1994. Turf weeds and their control. ASA, CSSA, Madison, WI. 259 pp.

Turley, D. B., Wright, G. and Hebden, P. 1998. Changes in weed seed banks during long-term set-aside. Aspects Appl. Biol. 51: 265-272.

Tzvelev, N. N. 1993. Notes on some Polygonum species in Eastern Europe. Novitates Systematicae Plantarum Vascularium 29: 134-142.

Utkhede, R. S., Koch, C. A., Menzies, J. G. and Ehret, D. L. 2001. Host range of a powdery mildew (Erysiphe orontii) on tomato. Can. J. Plant Sci. 81: 179-182.

Uva, R., Neal, J. C. and DiTomaso, J. M. 1997. Weeds of the northeast. Comstock Publishing Associates, Ithaca and London. 397 pp.

Vlk, F. and Holubcova, M. 1972. An investigation into the host range of the garlic race of stem-eelworm, Ditylenchus dipsaci Kuhn. Sbornik Vysoke Skoly Zemedeske v Praze, Rada A fakulta agronomicka 17: 5-181.

Vysochina, G. I. 1999. Dynamics of content and flavonoid component composition in Polygonum aviculare. Rastitel'nye Resursy 35: 67-74 [in Russian, English abstract].

Warwick, M. A. 1984. Buried seeds in arable soils in Scotland. Weed Res. 4: 261-268.

Watson, L. and Dallwitz, M. J. 1992-onwards. The families of flowering plants: descriptions, illustrations, identification, and information retrieval. [Online] Available: Version: 14th December 2000. http://biodiversity.uno.edu/delta [2003 Aug.].

Watson, S. J., Mauchline, A. L., Brown, V. K. and FroudWilliams, R. J. 2003. Post-dispersal losses of Stellaria media and Polygonum aviculare seeds in spring barley (Hordeum vulgare). Aspects Appl. Biol. 69: 203-208

Wilson, J. D. 2001. Weeds as a food resource for farmland birds: what, where and how many should we leave. BCPC ConferenceWeeds 2001. pp. 391-398.

Wilson, J. D., Morris, A. J., Arroyo, B. E., Clark, S. C. and Bradbury, R. B. 1999. A review of the abundance and diversity of invertebrate and plant foods of granivorous birds in northern Europe in relation to agricultural change. Agric. Ecosyst. Environ. 75: $13-30$.

Wilson, P. J. and Aebischer, N. J. 1995. The distribution of dicotyledonous arable weeds in relation to distance from field edge. J. Appl. Ecol. 32: 295-310.

Witts, K. J. 1960. The germination of Polygonum species in the field and in the glass-house. J. Ecol. 48: 215-217.

Wodehouse, R. P. 1931. Pollen grains in the identification and classification of plants VI. Polygonaceae. Am. J. Bot. 18: 747-764. Wolf, S. J. and McNeill, J. 1986. Synopsis and achene morphology of Polygonum section Polygonum (Polygonaceae) in Canada. Rhodora 88: 457-479.
Wolf, S. J. and McNeill, J. 1987. Cytotaxonomic studies on Polygonum section Polygonum in eastern Canada and the adjacent United States. Can. J. Bot. 65: 647-652.

Woodcock, E. F. 1914. Observations on the development and germination of seed in certain Polygonaceae. Am. J. Bot. 9: 454-476. Wren, R. C. 1992. Potter's new encyclopedia of botanical drugs and preparations. Saffron Walden, Essex, UK. 362 pp.

Wright, D. and Baloch, M. K. 1999. Effects of seven common arable weeds on the yield of normal and semi-leafless pea varieties. Tests Agrochem. Cult. 20: 54-55.

Yanishevsky, D. E. 1927. Polygonum salsugineum M. B. Ekologo-morfologicheskii ocherk. Izvestiya Seratovskoga in-ta krajevedeniya 2: 51-75 [in Russian].

Wurtz, T. L. 1995. Domestic geese: biological weed control in an agricultural setting. Ecol. Appl. 5: 570-578.

Younie, D., Taylor, D., Coutts, M., Matheson, S., Wright, G. and Squire G. 2002. Effect of organic crop rotations on long-term development of the weed seedbank. UK Organic Research 2002: Proc. COR Conference, 26-28 March 2002, Aberystwyth, UK. pp. 215-220.

Yurtseva, O. V. 1998. Self-pollination in species of Polygonum subsection Polygonum. Bull. Mosk. Soc. Nat. 5: 61-67.

Yurtseva, O. V. 2001. Ultrastructure of achene surface in Polygonum section Polygonum (Polygonaceae) in Russia. Nordic J. Bot. 21: 513-528.

Yurtseva, O. V. and Kramina, T. E. 2003. Variability of species of the subsection Polygonum of the genus Polygonum (Polygonaceae) in connection with their possible hybridization. Bot. Zhurn. 88: 9-25.

Yurtseva, O. V., Yakolevleva, N. D. and Ivanova-Radkevich, T. I. 1999. Heterocarpy in Polygonum aviculare L. s. str. and related species (Polygonum subsect. Polygonum). Byull. Mosk. Obshch. Ispyt. Prir. Biol. 104: 13-20. [in Russian, English abstract].

Zhang, B. Y., Chen, H. G. and Zhou, T. W. 1992. Exploration on colored plastic film mulch for controlling weeds in tomato and maize fields. Plant Prot. 6: 40-41.

Zitter, A. T. 2003. A checklist of major weeds and crops as natural hosts for plant viruses in the Northeast. Department of Plant Pathology, Cornell University, Ithaca, New York. [Online] Available: http://vegetablemdonline.ppath.cornell.edu/Tables/ WeedHostTable.html [2003 Aug.].

Zolda, P. 2001. The behaviour and ecology of Bembecinus hungaricus Frivaldsky (Hymenoptera: Apoidea: Sphecidae) in Austria. Beiträge zur Entomofaunistik 2: 3-14.

Zundel, G. L. 1953. The Ustilaginales of the world. Contr. Dept. Bot. Pennsylvania State Coll. School Agric. 176: 1-410.

Zwerger, P. 1990. Model trials on the influence of nitrogen fertilization on the seed production and competitiveness of Fallopia convolvulus (L.) A. Love and three Polygonum species. Z. Pflanzenk. Pflanzen. 12: 107-113 [in German, English abstract].

\section{APPENDIX 1-GLOSSARY OF TERMS}

Anisocitic-(of a stomatal complex) in which three of the subsidiary cells surrounding stomata are unequal in size.

Antipods - the cells of the female gametophyte present at the chalazal end (opposed to the micropyle) of the mature embryo sac. Bitegmic - (of an ovule) with two integuments, internal and external. Capitate - abruptly enlarged distally to a relatively short, terminal portion that is basically round in transverse section.

Crassinucellate - (of an ovule in which) the megagametophyte is located deep into nucellus (the tissue within the ovule in which the female gametophyte develops).

Cucullate-hood-shaped.

Decumbent—-spreading horizontally but then growing upwards. 
Divaricate - widely spreading and often more or less horizontal Elliptic — widest at the middle, ratio length:width $=2: 1$.

Lanceolate-widest below the middle, elongate, with ratio length:width $\geq 3$ : 1 .

Lacerate-laciniate, slashed into irregular lobes.

Linear-elongate and narrow, widest at the middle, ratio length: width $\geq 10: 1$.

Monochasial cyme - a determined inflorescence in which branches are monopodial (inflorescence branches arise singly).

Oblanceolate - inversely lanceolate, widest above the middle.

Ovate - egg shaped, widest below the middle; ratio length: width as in elliptic.

Obovate-inversely ovate, widest above the middle; ratio length:width as in elliptic.

Orthotropous - (of an ovule) erect, so that the micropyle faces away from the placenta.

Porogamous - of the fertilization in which pollen tubes pass through the stylar canal and the ovule micropyle.

S-type-(of sieve tube plastids) having starch grains of different size.

Scorpioid-(of a cymose monochasial inflorescence) branching alternately on one side and then the other with the main axis coiled like the tail of a scorpion.

Spathulate-elongate, broadest near a rounded apex, gradually attenuate to a narrower base; like the outline of the broad face of a spatula blade.
Spiciform-resembling a spike (an elongate, simple and indeterminate axis bearing sessile flowers), but not strictly such.

Striate-tubercled - of achenes having tubercles arranged in rows on the exocarp.

Subprolate-describing the shape of a pollen grain in which the ratio between the polar axis and the equatorial diameter is $1.14-1.33$

Syncarpous - (gynoecium) with fused carpels.

Tepals-elements of an undifferentiated perianth (when sepals and petals are not differentiated)

Tectate - pollen grains with a tectum: the layer of sexine (the outer layer of the sporoderm - the pollen grain wall), which forms a roof over the columellae, granules, or other infratectal elements. Tetrasporangiate - of anthers having four pollen sacs.

Thyrse - a compound inflorescence in which the main axis is indeterminate and the lateral ones (of lateral inflorescences) are determinate, cymes.

Tricolporate-describing pollen grains with three ectocolpi or pores. Tubercles - spherical or dome-like structures encountered on the exocarp of achenes.

Very narrowly elliptic — widest at the middle, ratio length:width $=6: 1$.

Vestured pit - a bordered pit (a depression in a cell wall with secondary thickening; in such an area only primary walls and middle lamella are present). 